\title{
Effect of LCFeCr Alloy Additions on the Non-metallic Inclusion Characteristics in Ti-Containing Ferritic Stainless Steel
}

\author{
YONG WANG, MIN KYO OH, TAE SUNG KIM, ANDREY KARASEV, \\ WANGZHONG MU, JOO HYUN PARK, and PÄR G. JÖNSSON
}

\begin{abstract}
The influence of commercial low carbon ferrochromium ( $\mathrm{LCFeCr}$ ) additions on the inclusion characteristics in Ti-containing ferritic stainless steel was studied by laboratory experiment in this work. The inclusions in steel before and after the $\mathrm{FeCr}$ alloy additions were investigated through systematic samplings and microscopy investigations of the liquid steel. Different types of inclusions in the $\mathrm{FeCr}$ alloy and steel were detected and the evolution of the inclusion characteristics (e.g., composition, size, morphology, and number density) were investigated. The results showed that the $\mathrm{Ti}$ content decreased after the $\mathrm{FeCr}$ alloy additions. Furthermore, $\mathrm{MnCr}_{2} \mathrm{O}_{4}$ spinel inclusions originating from the $\mathrm{FeCr}$ alloys transformed into $\mathrm{Ti}_{2} \mathrm{O}_{3}-\mathrm{Cr}_{2} \mathrm{O}_{3}$-based liquid inclusions and $\mathrm{Ti}_{2} \mathrm{O}_{3}$-rich solid inclusions. They were formed due to the reactions between $\mathrm{MnCr}_{2} \mathrm{O}_{4}$ and TiN inclusions or dissolved Ti in molten steel. The ratio of $\mathrm{Ti} / \mathrm{Al}$ in the steel melt has a direct influence on the evolution of inclusions from thermodynamic calculations. The addition of $\mathrm{FeCr}$ alloys caused an increased number density of these $\mathrm{Ti}_{2} \mathrm{O}_{3}$-containing inclusions and TiN inclusions up to 8 minutes from the time of alloy addition. The increased $\mathrm{Cr}$ content from 16 to 24 mass pct due to the $\mathrm{FeCr}$ additions can increase the critical $\mathrm{N}$ content to form TiN inclusions at a specific Ti content. Overall, this study has contributed to the understanding the behavior of inclusions from $\mathrm{LCFeCr}$ alloy during the alloying process in Ti-containing steel.
\end{abstract}

https://doi.org/10.1007/s11663-021-02296-2

(c) The Author(s) 2021

\section{INTRODUCTION}

FERRITIC stainless steel (FSS) grades are essentially $\mathrm{Fe}-\mathrm{Cr}$ binary alloys containing 12 to 30 mass pet $\mathrm{Cr}$. Recently, ferritic stainless steels containing chromium up to 30 mass pet with ultra-low carbon and nitrogen contents have been developed for good corrosion resistance and high formability to replace austenitic stainless steels. ${ }^{[1,2]}$ Titanium has been widely used as an alloying element in stainless steel to suppress chromium nitride precipitations at grain boundaries by stabilizing

YONG WANG, ANDREY KARASEV, WANGZHONG MU, and PÄR G. JÖNSSON are with the Department of Materials Science and Engineering, KTH Royal Institute of Technology, Brinellvägen 23, SE-100 44 Stockholm, Sweden. Contact e-mail: yongwang@kth.se MIN KYO OH and TAE SUNG KIM are with the Department of Materials Science and Chemical Engineering, Hanyang University, Ansan 15588, Korea. JOO HYUN PARK is with the Department of Materials Science and Engineering, KTH Royal Institute of Technology and also with the Department of Materials Science and Chemical Engineering, Hanyang University. Contact e-mail: basicity@hanyang.ac.kr

Manuscript submitted May 8, 2021, accepted July 31, 2021

Article published online September 8, 2021 nitrogen, which substantially improves the resistance to intergranular corrosion. ${ }^{[3]}$ TiN or titanium oxides, $\mathrm{TiO}_{x}$, in liquid steel are known to help the formation of an equiaxed fine-grain structure due to a heterogeneous nucleation of $\delta$-ferrite during solidification caused by their small lattice misfit. ${ }^{[4-9]}$ On the other hand, an excessive formation of those inclusions can cause nozzle clogging problems during continuous casting and subsequently lead to various defects in the final products. ${ }^{[8,10]}$ Therefore, controlling the interstitial contents at an optimum level is important for developing desirable properties in these stainless steels.

Many researchers have investigated the inclusion characteristic changes during different stages of the steelmaking process. Most of these investigations have focused on areas such as slag-metal reactions, inclusion formation, growth, modification, floatation, and removal. The main origins of inclusions could be the slag/fluxes, refractory, deoxidizers, ferroalloys, or air to which liquid steel comes in contact during the process. One area of interest is that the additions of ferroalloys can not only increase the content of the alloying element, but they also can have an unintentional effect 
on the inclusions in the steel melt, which decreases the steel cleanliness. This is an area that has not been widely explored.

Wijk and Brabie ${ }^{[11]}$ performed laboratory experiments to study the influence of FeSi alloy (standard, granulated, high purity) additions on the inclusion characteristics in steel melts. They reported that the addition of a high-purity FeSi alloy resulted in the formation of fewer inclusions compared to when using a standard FeSi alloy. Also, the effects of Al and $\mathrm{Ca}$ in FeSi alloys on the composition evolution of inclusions in different steel melt have been well investigated by several researchers. ${ }^{[12-17]}$ They reported that the high Al-containing FeSi alloys can significantly increase the formation of pure $\mathrm{Al}_{2} \mathrm{O}_{3}$ and/or $\mathrm{MgAl}_{2} \mathrm{O}_{4}$ spinel inclusions in liquid steel. The high $\mathrm{Ca}$-containing $\mathrm{FeSi}$ alloys can modify $\mathrm{Al}_{2} \mathrm{O}_{3}$ and $\mathrm{MgO} \cdot \mathrm{Al}_{2} \mathrm{O}_{3}$ solid inclusions into liquid $\mathrm{CaO}-\mathrm{Al}_{2} \mathrm{O}_{3}$ inclusions.

Sjökvist et al. ${ }^{[18]}$ investigated the effect of FeMn additions on the inclusion characteristics in steel. They proposed that different FeMn grades only have a temporary influence on the inclusion characteristics in steel during ladle refining since the cleanliness of final steel product showed an equal level for all FeMn grades. Pande et al. ${ }^{[19,20]}$ revealed that FeTi can act as a potential source of oxygen, which lead to the formation of new inclusions during the dissolution of the alloy in steel melt. They also studied the influence of impurities in FeTi70 and FeTi35 alloys on steel cleanliness in an industrial process. Their results showed that the number of generated inclusions was higher for a FeTi35 addition compared to a FeTi70 addition, which was attributed to the presence of larger contents of impurities in the FeTi35 alloys. ${ }^{[21]}$ Also, Dorrer et al. ${ }^{[22]}$ reported that the FeTi75 additions can cause the formation of a new population of Ti-containing alumina inclusions which increased clogging tendency. Sjökvist et al. ${ }^{[23]}$ also investigated the inclusions in high carbon ferrochrome ( $\mathrm{HCFeCr}$ ) alloys and the behavior of the inclusions in steel after additions of these alloys to steel. They reported that $\mathrm{MnS}$ and $(\mathrm{Cr}, \mathrm{Ti})(\mathrm{C}, \mathrm{N})$ inclusions from $\mathrm{HCFeCr}$ alloys were dissolved together with the alloys, and that complex sulfide ( $\mathrm{Cr}, \mathrm{Fe}, \mathrm{Mn}, \mathrm{Ti}) \mathrm{S}$ formed during solidification. However, $\mathrm{HCFeCr}$ alloys are usually added earlier in the steelmaking process. Therefore, it is more interesting to study low carbon ferrochrome $(\mathrm{LCFeCr})$ alloys that are added late in the process. ${ }^{[24,25]}$ Reviews in this area indicate a general need for more information about the influence of ferroalloys on the inclusion characteristics in steel. Moreover, the evolution mechanism of inclusions from $\mathrm{LCFeCr}$ alloys in molten steel has been rarely investigated.

In this study, the inclusions in commercial $\mathrm{LCFeCr}$ alloys were first analyzed. Then laboratory alloying experiments were carried out using Ti-containing ferritic stainless steel (modified STS430 grade) as experimental materials. The target steel grade after the $\mathrm{FeCr}$ alloy addition is 446 grade containing 23 to 27 mass pet $\mathrm{Cr}$ content. The aim is to investigate the effects of $\mathrm{FeCr}$ additions on the inclusion transformation thermodynamics and kinetics in steel.

\section{EXPERIMENTAL}

\section{A. Experimental Procedure}

The alloying experiment was carried out using a high-frequency induction furnace, of which a schematic diagram is shown in Figure 1(a). The quartz reaction chamber was initially evacuated prior to performing the experiments using a mechanical rotary pump; the chamber was subsequently filled with a highly purified Ar-3 pct $\mathrm{H}_{2}$ gas mixture controlled using a mass flow controller. Impurities in the Ar-3 pct $\mathrm{H}_{2}$ gas mixture were removed by passing the gas through Drierite (W.A. Hammond Drierite Co. Ltd., Xenia, $\mathrm{OH}$ ), silica gel, and Mg turnings at $723 \mathrm{~K}\left(450{ }^{\circ} \mathrm{C}\right)$. The 430 stainless steel ingot (500 g) was melted in a fused $\mathrm{MgO}$ crucible (99.9 pct purity, $60 \times 50 \times 120 \mathrm{~mm}$ ) with a graphite heater for induction heating; the heater was surrounded by insulation. The experimental temperature was $1873 \mathrm{~K}$ $\left(1600{ }^{\circ} \mathrm{C}\right)$, which was controlled within $\pm 2 \mathrm{~K}\left(2^{\circ} \mathrm{C}\right)$ using a B-type (Pt-30Rh/Pt-6Rh, mass pct) thermocouple and a proportional integral differential controller. After the temperature was stabilized for 30 minutes, an initial steel sample (S1) was taken using a quartz suction tube (ID $=4 \mathrm{~mm}$ ) and thereafter quenched in water. As soon as the initial sampling was completed, $85 \mathrm{~g} \mathrm{FeCr}$ alloy was added through the quartz tube $(14 \times 12 \times 500 \mathrm{~mm})$ under an Ar-3 pct $\mathrm{H}_{2}$ atmosphere. The compositions of steel and $\mathrm{FeCr}$ alloy are listed in Table I. Then, steel samples were taken at various times (S2 at 3 minutes, S3 at 8 minutes, S4 at 18 minutes, S5 at 30 minutes), as shown in Figure 1(b).

\section{B. Analysis and Characterization}

The chemical compositions of the steel samples were determined using inductively coupled plasma atomic emission spectrometry (ICP-AES, ACROS, SPECTRO). The oxygen and nitrogen contents were determined by using a LECO combustion analyzer. Three-dimensional observation after the electrolytic extraction was used to observe the exact morphology, composition, and size of inclusions in the $\mathrm{FeCr}$ alloy and steel samples. For this experiment, a 10 pct AA solution (10 pct acetylacetone, 1 pct tetramethylammonium chloride, and methanol) was used as the electrolyte, and a $750 \mathrm{~mA}$ current was applied for 3 hours. The extracted inclusions were filtered out by a vacuum pump and laid on a membrane filter with a pore size of $0.1 \mu \mathrm{m}$. Once completely dried, the filter was coated with platinum. Next, the inclusions on the filter were evaluated by using field emission scanning electron microscopy analysis (FE-SEM; TESCAN model MIRA 3) equipped with an energy-dispersive X-ray spectroscope (EDS). Besides, the characterization of inclusions, i.e., number density, size distribution, and chemical composition, in the steel samples was performed using a field-emission scanning electron microscopy (FE-SEM). The inclusions in the samples were observed using the automated inclusion analysis system with the following settings: $1-\mu \mathrm{m}$-limit diameter for inclusion detection in the $10 \mathrm{~mm}^{2}$ area. 


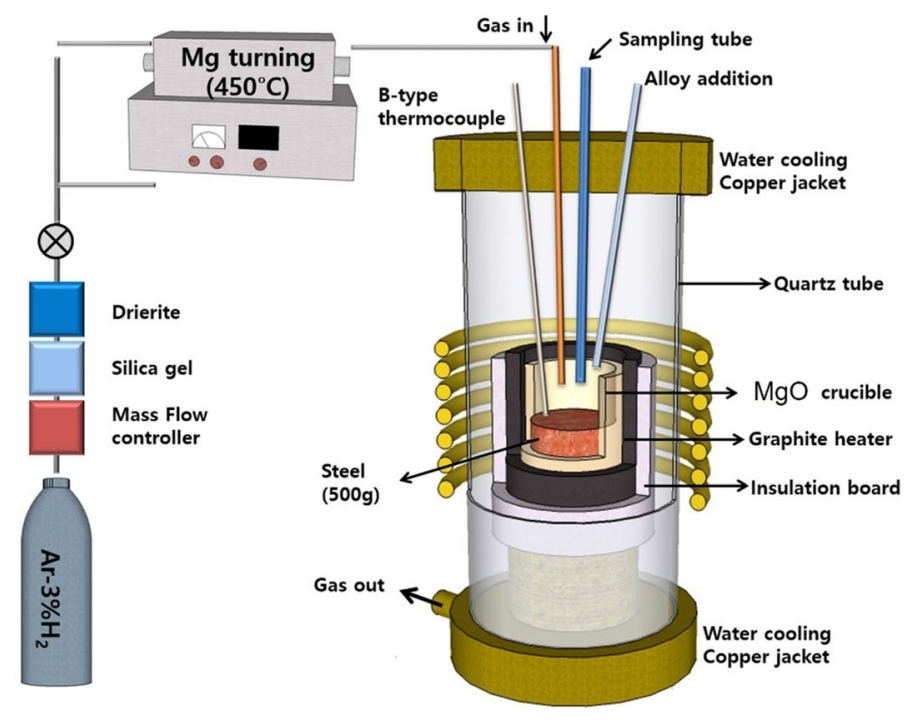

(a)

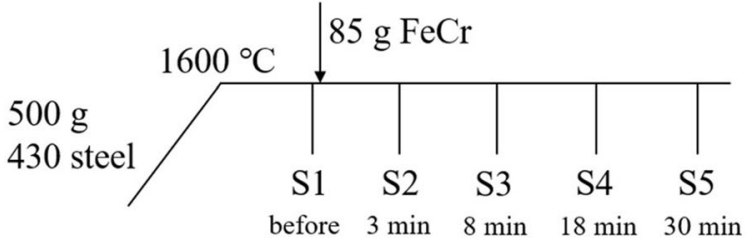

(b)

Fig. 1-Schematic diagram of the experimental apparatus $(a)$ and schematic illustration of the sampling time $(b)$.

Table I. Chemical Compositions of Steel and FeCr Alloys Used in the Present Study (Mass Pct).

\begin{tabular}{llcccccccc}
\hline Elements & $\mathrm{C}$ & $\mathrm{Si}$ & $\mathrm{Mn}$ & $\mathrm{Cr}$ & $\mathrm{Ti}$ & $\mathrm{Al}$ & $\mathrm{N}$ & $\mathrm{S}$ & $\mathrm{O}$ \\
\hline 430 Steel & 0.004 & 0.12 & 0.15 & 16.5 & 0.22 & 0.012 & 0.006 & 0.003 & 0.01 \\
FeCr & 0.03 & 0.41 & 0.25 & 71.8 & 0.12 & 0.05 & 0.021 & 0.002 & 0.078 \\
\hline
\end{tabular}

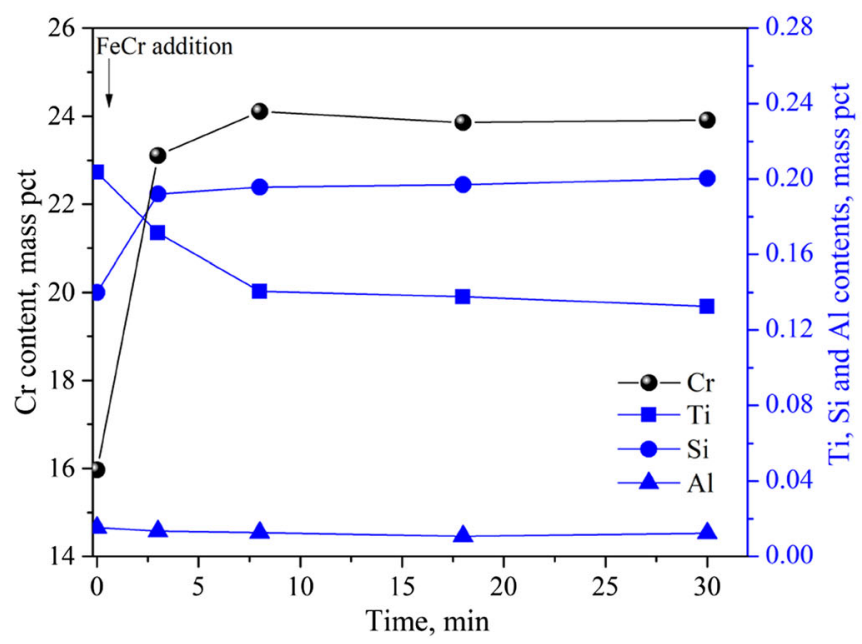

(a)

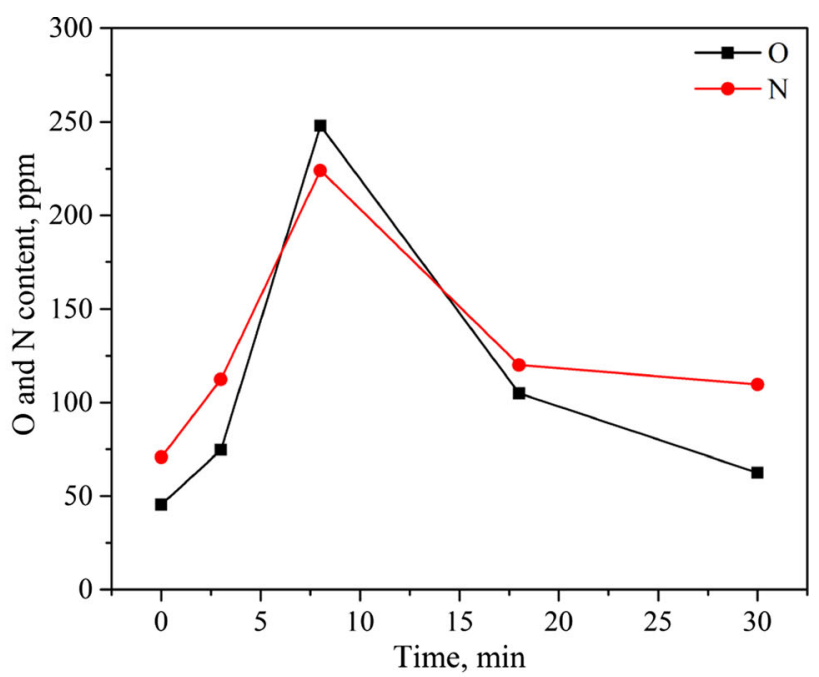

(b)

Fig. 2-Typical composition changes versus time $(a) \mathrm{Cr}$, Ti, $\mathrm{Si}$, and $\mathrm{Al}$ contents, $(b) \mathrm{O}$ and $\mathrm{N}$ contents.

\section{RESULTS AND DISCUSSION}

\section{A. Changes in Metal Compositions by $\mathrm{FeCr}$ Alloy} Addition

Figure 2 illustrates how the contents of typical elements change with time during the experiment. It can be seen that the initial $\mathrm{Cr}$ content before $\mathrm{FeCr}$ addition was about 16 mass pet, which corresponds to time 0 . Three minutes later after $\mathrm{FeCr}$ addition, the $\mathrm{Cr}$ content increased to 23 mass pct. After the initial sharp increase, it slightly increased to 24 mass pct and remained at a steady level later. The Si content sharply increased after 3 minutes of $\mathrm{FeCr}$ addition and then maintained a constant value with time during the experiment. The increased Si content might come from $\mathrm{Si}$ in the added $\mathrm{FeCr}$ alloy (0.41 mass pct). With respect 
to the Ti content, it showed an opposite tendency to that of Si content. The Ti content was about 0.21 mass pet at the beginning of the experiment, then it drastically decreased to 0.15 mass pct after 8 minutes from $\mathrm{FeCr}$ addition and thereafter had an almost constant value. The decrease of $\mathrm{Ti}$ in the melt might be due to the reactions between $\mathrm{Ti}$ and the inclusions from $\mathrm{FeCr}$ alloys, which are discussed in detail in Section III. In addition, the $\mathrm{Al}$ content remained at a steady level at about 0.01 mass pet with small fluctuations for the duration of the experiment. It can be inferred that the Al content is hardly influenced by the addition of the investigated $\mathrm{FeCr}$ alloy, which contains a small $\mathrm{Al}$ content $(0.05$ mass pct).

The total oxygen (T.O) content was about $100 \mathrm{ppm}$ in the original steel (Table I), and it decreased to about 45 ppm after melting and stabilization. This was not only due to the removal of $\mathrm{O}$ by the Ar- 3 pct $\mathrm{H}_{2}$ gas mixture, but also due to the partial removal of oxide inclusions by floatation and adherence to the crucible wall. After the addition of $\mathrm{FeCr}$ alloys, the $\mathrm{O}$ content significantly increased and reached a maximum value after 8 minutes. Thereafter, it sharply decreased to a value of approximately $60 \mathrm{ppm}$ due to the floatation and removal of oxide inclusions. The nitrogen $(\mathrm{N})$ content showed a similar tendency to that of the $\mathrm{O}$ content, which also reached a peak value at 8 minutes. One possible explanation is that the melt might be re-oxidized during the addition of $\mathrm{FeCr}$ alloys. Another reason might be due to the reactions happened after $\mathrm{FeCr}$ additions, which are discussed in detail in Section III. The final N and $\mathrm{O}$ contents were slightly higher than those in the sample $\mathrm{S} 1$ before $\mathrm{FeCr}$ additions.

\section{B. Characterization of Inclusions in FeCr Alloys and Steel Samples}

\section{Inclusions in $\mathrm{FeCr}$ alloys}

The characteristics of inclusions found in the investigated $\mathrm{FeCr}$ alloys are shown in Table II. The major type of inclusion is $\mathrm{MnO}-\mathrm{Cr}_{2} \mathrm{O}_{3}$, which accounts for approximately 73 pct of the total inclusions. Based on their compositions and typical polygonal morphologies, they belong to the $\mathrm{MnCr}_{2} \mathrm{O}_{4}$ spinel group inclusions. Moreover, they have the largest size distribution (3 to 72 $\mu \mathrm{m})$ compared to the other types of inclusions. This was reported in the previous papers which combined the results obtained from both the film filters and metal surface after electrolytic extraction. ${ }^{[26]}$ The following type is pure $\mathrm{Al}_{2} \mathrm{O}_{3}$ inclusion $(\sim 19$ pct) with a size distribution of 4 to $20 \mu \mathrm{m}$. Finally, the $\mathrm{Al}_{2} \mathrm{O}_{3}-\mathrm{SiO}_{2}-$ $\mathrm{CaO}-\mathrm{MgO}$ complex oxide inclusions were found $(\sim 8$ pct). Their evolution behaviors in the steel melt after $\mathrm{FeCr}$ addition are discussed in the following sections.

\section{Inclusion morphology in steel melt after $\mathrm{FeCr}$ additions}

Figure 3 shows the morphologies and compositions of different types of inclusions in the steel samples before and after the $\mathrm{FeCr}$ alloy additions. The detailed inclusion types in each sample are shown in Table III. In sample $\mathrm{S} 1$ (before $\mathrm{FeCr}$ addition), the main type was
TiN inclusions, which were present both as single particles and clusters (Figure 3(a)). They belong to the cubic or triangular-shaped crystal systems with a high melting temperature and hardness, resulting in a difficulty to be deformed during the steel processing. ${ }^{[27]} \mathrm{TiN}$ clusters usually have a larger size, which may be broken up into smaller TiN particles in a stringer shape during the rolling process. ${ }^{[28,29]}$ The microvoids in such stringers will act as initiation sites for pitting corrosion or the initiation of stress corrosion cracking when exposed to an aqueous solution.

In terms of oxide inclusions, nearly spherical $\mathrm{TiO}_{x}-$ $\mathrm{Al}_{2} \mathrm{O}_{3}$ (Figure 3(b)) and irregular $\mathrm{TiO}_{x}$ (Figure 3(c)) inclusions were observed. In addition, polyhedral $\mathrm{TiO}_{x}-\mathrm{Al}_{2} \mathrm{O}_{3}-\mathrm{MgO}$ spinel group inclusions were found in all samples and they had similar morphologies (Figure 3(d)). A small amount of dissolved Mg probably originated from the reduction of $\mathrm{MgO}$ in the crucible by soluble $\mathrm{Al}$ in liquid steel, as expressed in Eq. [1]. ${ }^{[30]}$ With the generation of dissolved $\mathrm{Mg}, \mathrm{MgO} \cdot \mathrm{Al}_{2} \mathrm{O}_{3}$ inclusions can be easily formed according to reactions [2] and [3]. ${ }^{[31]}$ The possible formation mechanisms of $\mathrm{TiO}_{x}-$ $\mathrm{Al}_{2} \mathrm{O}_{3}-\mathrm{MgO}$ inclusions can be explained by the reaction between soluble $\mathrm{Ti}$ and $\mathrm{MgO} \cdot \mathrm{Al}_{2} \mathrm{O}_{3}$ inclusions, as given by Eq. [4]. ${ }^{[32]}$ Besides, inclusions with a $\mathrm{MgAl}_{2} \mathrm{O}_{4}$ core and a TiN out layer were also observed (Figure 3(e)). Many studies have demonstrated that a $\mathrm{MgAl}_{2} \mathrm{O}_{4}$ spinel has a high potential for acting as a TiN nucleation site because of the low lattice disregistry (4.88) between $\mathrm{MgAl}_{2} \mathrm{O}_{4}$ and $\mathrm{TiN}$ and relatively higher one (17.48) between $\mathrm{Al}_{2} \mathrm{O}_{3}$ and TiN. ${ }^{[33-35]}$ Also, irregular $\mathrm{Al}_{2} \mathrm{O}_{3}$ inclusions were found in the extracted samples before and after $\mathrm{FeCr}$ addition (Figure 3(f)). One possible origin can be from the added $\mathrm{FeCr}$ alloys. However, they were almost undetected by the automatic SEM analysis, which might be due to their small number density. Therefore, they are not discussed in the present study.

$$
\begin{aligned}
& 3(\mathrm{MgO})^{\text {crucible }}+2[\mathrm{Al}]=\left(\mathrm{Al}_{2} \mathrm{O}_{3}\right)^{\text {slag }}+3[\mathrm{Mg}] \\
& x[\mathrm{Mg}]+2 y[\mathrm{Al}]+(x+3 y)[\mathrm{O}]=\left(x \mathrm{MgO} \cdot y \mathrm{Al}_{2} \mathrm{O}_{3}\right) \\
& x[\mathrm{Mg}]+x[\mathrm{O}]+y\left(\mathrm{Al}_{2} \mathrm{O}_{3}\right)=\left(x \mathrm{MgO} \cdot y \mathrm{Al}_{2} \mathrm{O}_{3}\right) \\
& 2[\mathrm{Ti}]+\left(x \mathrm{MgO} \cdot y \mathrm{Al}_{2} \mathrm{O}_{3}\right)=\mathrm{Ti}_{2} O_{3} \cdot(x-1) \mathrm{MgO} \\
& \cdot(y-1) \mathrm{Al}_{2} \mathrm{O}_{3}+[\mathrm{Mg}] \\
& +2[\mathrm{Al}]
\end{aligned}
$$

After the $\mathrm{FeCr}$ alloy addition, single $\mathrm{TiN}$ particles and clusters containing cubic crystals continued to be present in steel (Figure $3(\mathrm{~g})$ ) and some (Ti,Cr)N inclusions were observed (Figure 3(h)). Both TiN and $\mathrm{CrN}$ phases are known as the $\mathrm{NaCl}$ rock-salt structure face-centered cubic (FCC). Hence, $\mathrm{Cr}$ can be incorporated by replacing $\mathrm{Ti}$ in the substitutional site of $(\mathrm{Ti}, \mathrm{Cr})(\mathrm{N})$ solid solution based on the two-sublattice model due to their similar crystal structure. ${ }^{[36]}$ 


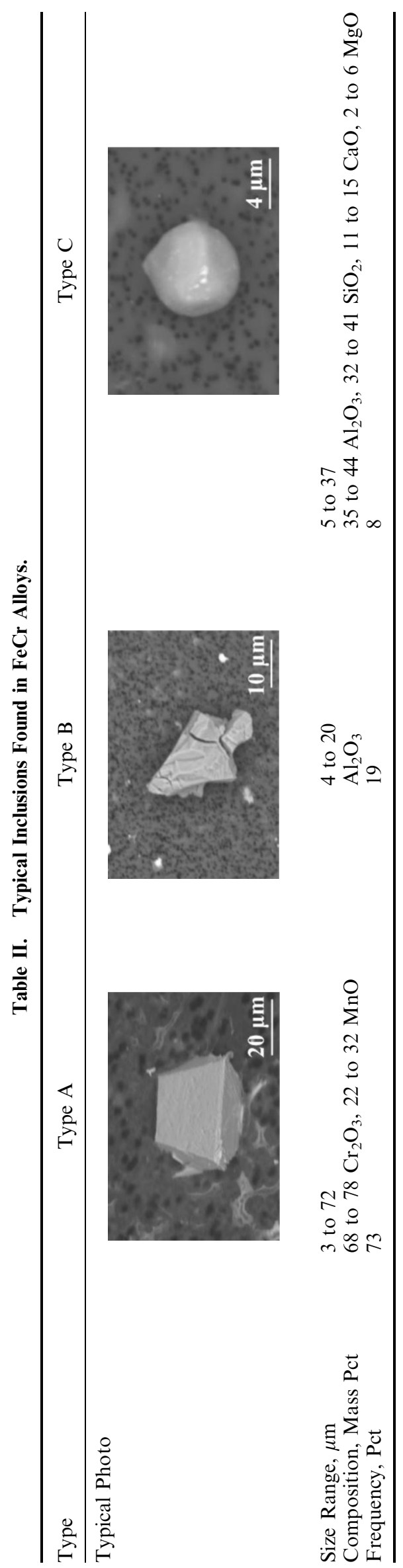




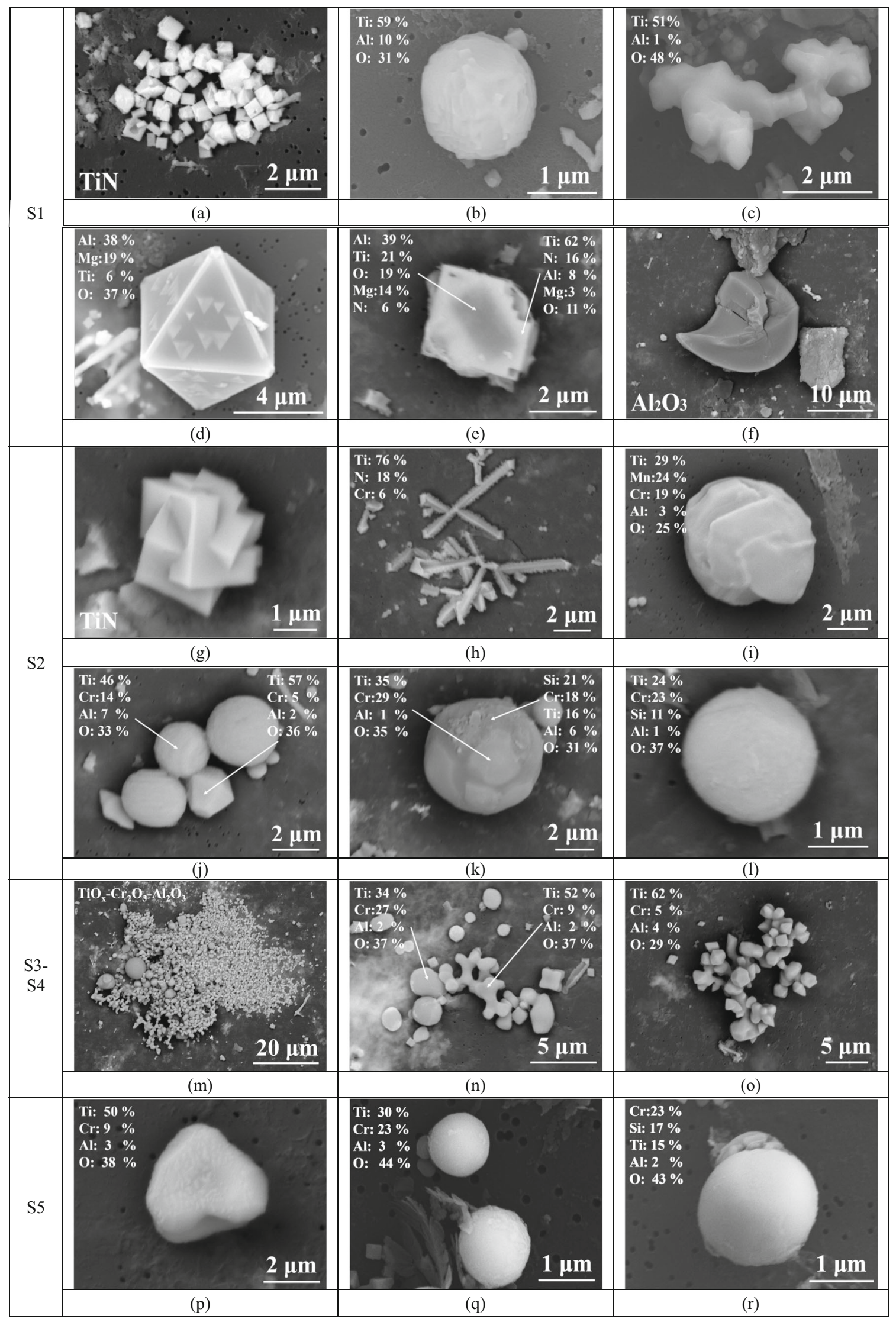

Fig. 3-Morphologies of typical inclusions observed in different samples, $(a)$ through $(f)$ in $\mathrm{S} 1,(g)$ through $(l)$ in $\mathrm{S} 2,(m)$ through $(o)$ in $\mathrm{S} 3$ and $\mathrm{S} 4,(p)$ through $(r)$ in S5. 
Table III. Type of Inclusions in FeCr Alloys and Steel Samples.

\begin{tabular}{lccccc}
\hline Type of Inclusion & Alloy & $\mathrm{S} 1(0 \mathrm{~min})$ & $\mathrm{S} 2(3 \mathrm{~min})$ & $\mathrm{S} 3(8 \mathrm{~min})$ & $\mathrm{S} 4(18 \mathrm{~min})$ \\
\hline $\mathrm{MnCr}_{2} \mathrm{O}_{4}$ & $\sqrt{ }$ & $\times$ & $\times$ & $\times$ & $\times$ \\
$\mathrm{Al}_{2} \mathrm{O}_{3}$ & $\sqrt{ }$ & $\times$ & $\sqrt{ }$ & $\sqrt{ }$ & $\times$ \\
$\mathrm{TiN}$ & $\times$ & $\sqrt{ }$ & $\sqrt{ }$ & $\times$ & $\sqrt{ }$ \\
$\mathrm{TiO}_{x}-\mathrm{Al}_{2} \mathrm{O}_{3}$ & $\times$ & $\sqrt{ }$ & $\times$ & $\times$ & $\times$ \\
$\mathrm{TiO}_{x}-\mathrm{Cr}_{2} \mathrm{O}_{3}-\mathrm{MnO}$ & $\times$ & $\times$ & $\sqrt{ }$ & $\times$ \\
$\mathrm{TiO}_{x}-\mathrm{Al}_{2} \mathrm{O}_{3}-\mathrm{MgO}$ & $\times$ & $\times$ & $\sqrt{ }$ & $\sqrt{ }$ \\
$\mathrm{TiO}_{x}-\mathrm{Cr}_{2} \mathrm{O}_{3}-\mathrm{Al}_{2} \mathrm{O}_{3}$ & $\times$ & $\times$ & $\sqrt{ }$ & $\sqrt{ }$ \\
$\mathrm{TiO}_{x}-\mathrm{Cr}_{2} \mathrm{O}_{3}-\mathrm{SiO}_{2}$ & $\times$ & $\times$ & $\sqrt{ }$ & $\sqrt{ }$ \\
\end{tabular}

It should be noted that very few inclusions that contained higher $\mathrm{MnO}$ contents (up to 33 mass pct) were observed only in sample S2 (Figure 3(i)), which might be due to the transformation of the $\mathrm{MnCr}_{2} \mathrm{O}_{4}$ inclusions in the $\mathrm{FeCr}$ alloys since no $\mathrm{MnO}$-containing inclusions were found in steel before the $\mathrm{FeCr}$ alloy addition. Moreover, the main types of oxide inclusions consisted of $\mathrm{TiO}_{x}, \mathrm{Cr}_{2} \mathrm{O}_{3}$, and $\mathrm{Al}_{2} \mathrm{O}_{3}$. They can be divided into two groups based on their compositions and morphologies: irregular shapes with lower $\mathrm{Cr}_{2} \mathrm{O}_{3}$ contents and nearly spherical shapes with higher $\mathrm{Cr}_{2} \mathrm{O}_{3}$ contents (Figure 3(j))

In addition, dual-phase inclusions containing both $\mathrm{TiO}_{x}-\mathrm{Cr}_{2} \mathrm{O}_{3}$ and $\mathrm{TiO}_{x}-\mathrm{Cr}_{2} \mathrm{O}_{3}-\mathrm{SiO}_{2}-\left(\mathrm{Al}_{2} \mathrm{O}_{3}\right)$ phases (Figure $3(\mathrm{k})$ ) and homogenous $\mathrm{TiO}_{x}-\mathrm{Cr}_{2} \mathrm{O}_{3}-\mathrm{SiO}_{2}$ inclusions (Figure 3(1)) were also observed. They were found in all the following samples (S2 to S5). Most of these $\mathrm{SiO}_{2}$-containing inclusions are spherical due to the fact that these inclusions are liquid at the experimental temperature. Moreover, the contents of $\mathrm{TiO}_{x}$ and $\mathrm{Cr}_{2} \mathrm{O}_{3}$ in the $\mathrm{TiO}_{x}-\mathrm{Cr}_{2} \mathrm{O}_{3}-\mathrm{SiO}_{2}-\left(\mathrm{Al}_{2} \mathrm{O}_{3}\right)$ phases are lower than those in the $\mathrm{TiO}_{x}-\mathrm{Cr}_{2} \mathrm{O}_{3}$ phases. Therefore, the $\mathrm{SiO}_{2}$-containing phase can be explained by the fact that the $\mathrm{TiO}_{x}$ and $\mathrm{Cr}_{2} \mathrm{O}_{3}$ in the inclusions are reduced by $\mathrm{Si}$ in the steel melts, as given in Eqs. [5] and [6]. ${ }^{[37]}$

$$
\begin{gathered}
2\left(\mathrm{Cr}_{2} \mathrm{O}_{3}\right)^{\text {inclusion }}+3[\mathrm{Si}]=3\left(\mathrm{SiO}_{2}\right)^{\text {inclusion }}+4[\mathrm{Cr}] \\
2\left(\mathrm{TiO}_{x}\right)^{\text {inclusion }}+x[\mathrm{Si}]=x\left(\mathrm{SiO}_{2}\right)^{\text {inclusion }}+2[\mathrm{Ti}]
\end{gathered}
$$

In sample $\mathrm{S} 3$ taken after 8 minutes of $\mathrm{FeCr}$ addition, the number of the $\mathrm{TiO}_{x}-\mathrm{Cr}_{2} \mathrm{O}_{3}-\mathrm{Al}_{2} \mathrm{O}_{3}$ inclusions greatly increased (Figure 3(m)). In samples S3 and S4, the typical compositions and morphologies of these $\mathrm{TiO}_{x}$ $\mathrm{Cr}_{2} \mathrm{O}_{3}-\mathrm{Al}_{2} \mathrm{O}_{3}$ inclusions are shown in (Figure 3(n)). The enlarged clusters which contained higher $\mathrm{TiO}_{x}$ contents (Figure 3(o)) were easily observed in these two samples.

In the final sample $\mathrm{S} 5$, irregular $\mathrm{TiO}_{x}-\left(\mathrm{Cr}_{2} \mathrm{O}_{3}-\mathrm{Al}_{2} \mathrm{O}_{3}\right)$ inclusions with lower $\mathrm{Cr}_{2} \mathrm{O}_{3}$ contents (Figure 3(p)) and spherical $\mathrm{TiO}_{x}-\mathrm{Cr}_{2} \mathrm{O}_{3}-\left(\mathrm{Al}_{2} \mathrm{O}_{3}\right)$ inclusions with higher $\mathrm{Cr}_{2} \mathrm{O}_{3}$ contents (Figure 3(q)) still represented the majority inclusion types. Moreover, a small number of spherical $\mathrm{TiO}_{x}-\mathrm{Cr}_{2} \mathrm{O}_{3}-\mathrm{SiO}_{2}$ inclusions (Figure 3(r)) were also observed.

\section{Inclusion composition, number, and size changes} in steel melt after $\mathrm{FeCr}$ additions

The equilibrium product titanium oxide changes its chemical composition with $\mathrm{Ti}$ content and oxygen partial pressure in the liquid steel. Previous studies ${ }^{[38-40]}$ showed that various valence states of titanium can be present in steel, such as $\mathrm{Ti}_{3} \mathrm{O}_{5}, \mathrm{Ti}_{2} \mathrm{O}_{3}$, and $\mathrm{TiO}_{2}$. The identification of equilibrium, the titanium oxide phases, and their activity information are very important for accurate thermodynamic analysis of the Ti-containing inclusions. ${ }^{[41]}$ Moreover, $\mathrm{TiO}_{x}-\mathrm{Cr}_{2} \mathrm{O}_{3}-\mathrm{Al}_{2} \mathrm{O}_{3}$ system inclusions were rarely reported by other researchers. Therefore, the equilibrium titanium oxides were first discussed based on the different oxygen partial pressures. Phase diagrams for the $\mathrm{TiO}_{x}-\mathrm{Cr}_{2} \mathrm{O}_{3}-\mathrm{Al}_{2} \mathrm{O}_{3}$ system at different oxygen partial pressures are illustrated in Figure 4, which were computed using FactSage 7.1 with the FactPS and FToxid databases at 1873 K (1600 $\left.{ }^{\circ} \mathrm{C}\right)$.

The phase diagram at $p\left(\mathrm{O}_{2}\right)=10^{-5}$ atm is similar to the phase diagram in air. Moreover, the rutile $\left(\mathrm{TiO}_{2}\right)$ phase is formed at the $\mathrm{TiO}_{x}$ corner, and also the $\mathrm{TiO}_{2}$ phase is a major phase in $\mathrm{TiO}_{x}$ in the cases as shown in Figure 4(a) through (c). When $p\left(\mathrm{O}_{2}\right)=10^{-10}$ atm, $\mathrm{Ti}_{5} \mathrm{O}_{9}$ is formed instead of $\mathrm{TiO}_{2}$ at the $\mathrm{TiO}_{x}$ corner (Figure $4(\mathrm{~d}))$. $\mathrm{Ti}_{3} \mathrm{O}_{5}$ becomes stable as a primary solid phase and all $\mathrm{Al}_{2} \mathrm{TiO}_{5}$ phases disappear at $p\left(\mathrm{O}_{2}\right)=10^{-12} \mathrm{~atm}$ (Figure 4(e)). In addition, the liquid phase region greatly increases and the fraction of $\mathrm{Ti}_{2} \mathrm{O}_{3}$ becomes larger than $\mathrm{TiO}_{2}$ in $\mathrm{TiO}_{x}$ when the oxygen partial pressure decreases from $p\left(\mathrm{O}_{2}\right)=10^{-10}$ to $p\left(\mathrm{O}_{2}\right)=10^{-12} \mathrm{~atm}$. As the oxygen partial pressure $p\left(\mathrm{O}_{2}\right)$ reaches a value of $10^{-15}$ atm, the liquid phase region continues to increase (Figure 4(f)). At the $\mathrm{TiO}_{x}$ corner, ilmenite $\left(\mathrm{Ti}_{2} \mathrm{O}_{3}+\right.$ $\left.\mathrm{Ti}_{2} \mathrm{Al}_{2} \mathrm{O}_{6}\right)$ is the dominant phase, while no $\mathrm{Ti}-\mathrm{Cr}-\mathrm{O}$ stable phase can be obtained. It should be noted that very few researchers reported this ternary system. Therefore, further work should be done to clarify the possible equilibrium phases. According to the discussions of these calculations, it can be concluded that the titanium oxide changes in the order of $\mathrm{TiO}_{2} \rightarrow \mathrm{Ti}_{5} \mathrm{O}_{9} \rightarrow$ $\mathrm{Ti}_{3} \mathrm{O}_{5} \rightarrow \mathrm{Ti}_{2} \mathrm{O}_{3}$ with a decrease of the oxygen partial pressure.

The calculated oxygen partial pressure $\left(=p\left(\mathrm{O}_{2}\right)\right)$ in the present study is about $10^{-15}$ atm based on Eqs. [7] through [9]. [30] 


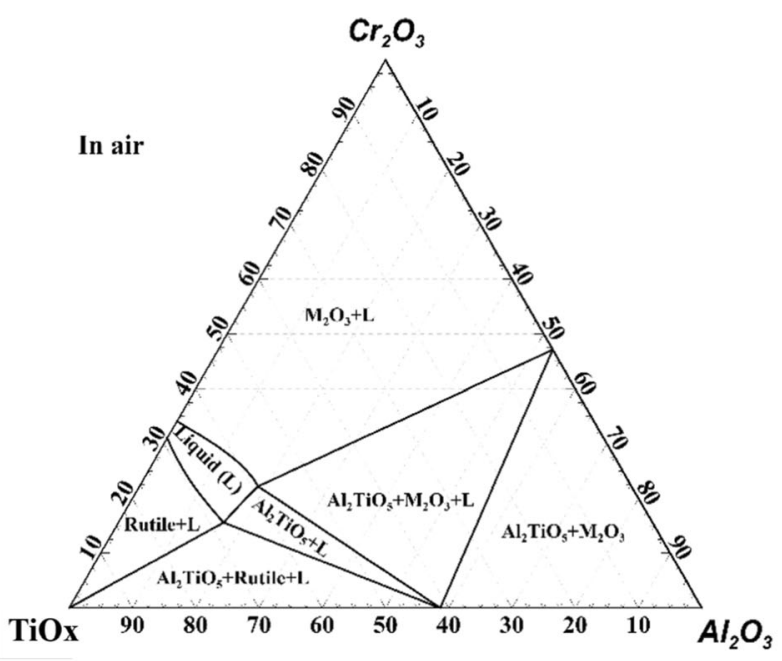

(a)

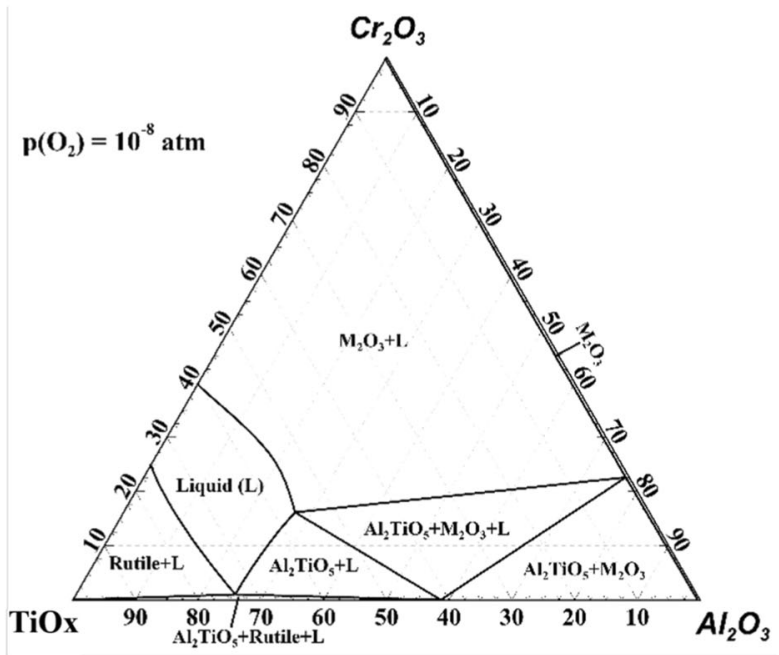

(c)

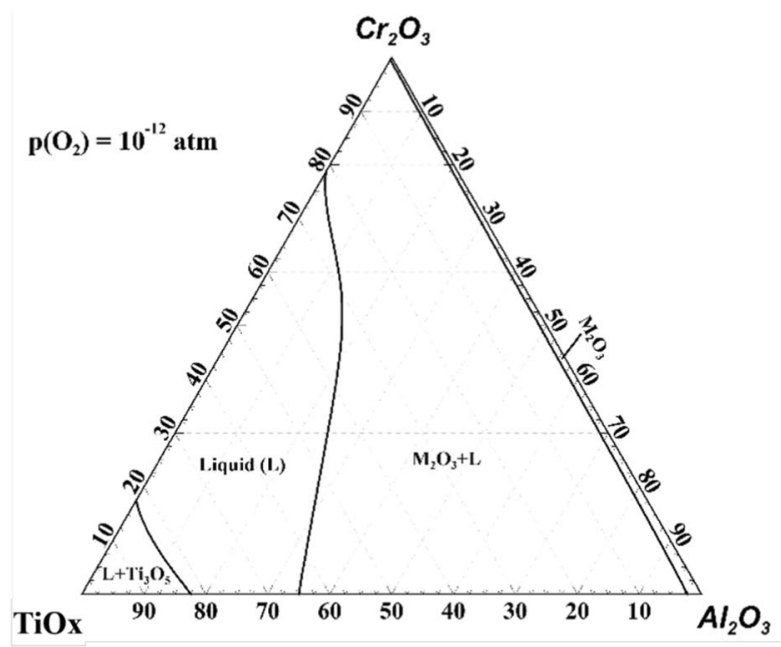

(e)

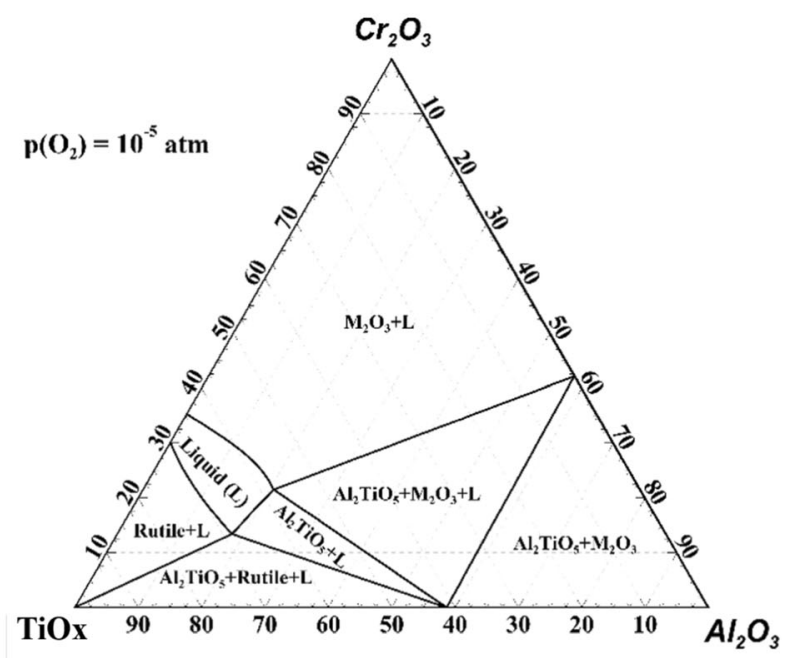

(b)

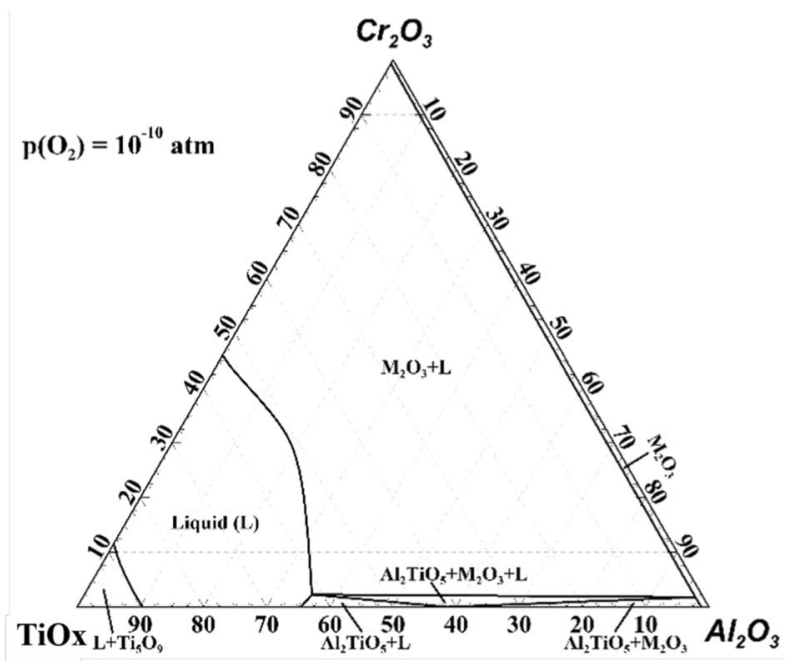

(d)

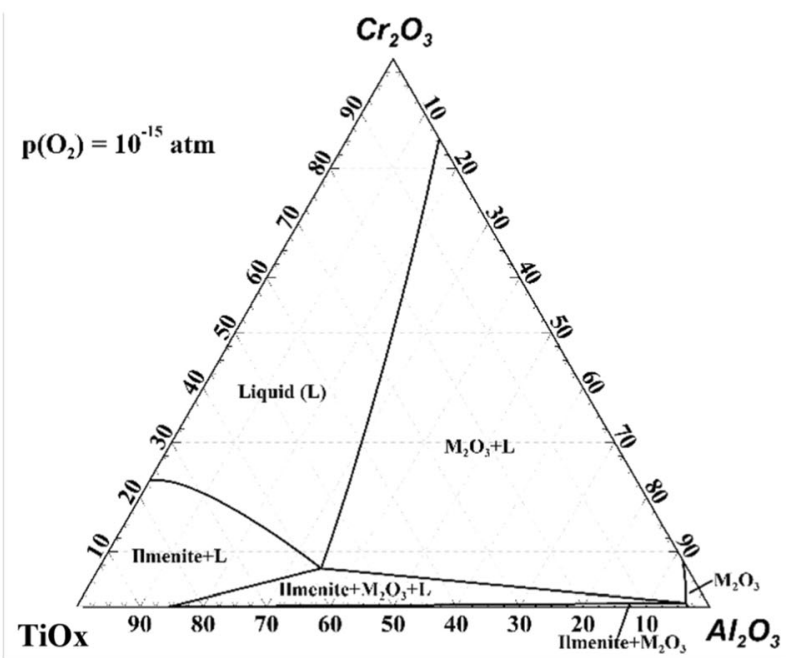

(f)

Fig. 4 - Calculated phase diagrams of the $\mathrm{TiO}_{x}-\mathrm{Cr}_{2} \mathrm{O}_{3}-\mathrm{Al}_{2} \mathrm{O}_{3}$ system at $1873 \mathrm{~K}\left(1600{ }^{\circ} \mathrm{C}\right)$ under varied oxygen partial pressures: $(a)$ in air, $(b)$ $p\left(\mathrm{O}_{2}\right)=10^{-5} \mathrm{~atm},(c) p\left(\mathrm{O}_{2}\right)=10^{-8} \mathrm{~atm},(d) p\left(\mathrm{O}_{2}\right)=10^{-10} \mathrm{~atm},(e) p\left(\mathrm{O}_{2}\right)=10^{-12} \mathrm{~atm}$, and $(f) p\left(\mathrm{O}_{2}\right)=10^{-15} \mathrm{~atm}$. (The axis number represents mass pct). 
Table IV. Interaction Parameters Used in the Present Study.

\begin{tabular}{|c|c|c|c|c|c|c|c|}
\hline$e_{i}^{j}\left(r_{i}^{j}\right)$ & $\mathrm{Cr}$ & $\mathrm{Si}$ & $\mathrm{Mn}$ & $\mathrm{Al}$ & $\mathrm{Ti}$ & $\mathrm{N}$ & $\mathrm{O}$ \\
\hline$\overline{\mathrm{O}}$ & $-0.032^{[30]}$ & $-0.066^{[30]}$ & $-0.037^{[30]}$ & $\begin{array}{l}-1.17^{[45]} \\
(-0.01)\end{array}$ & $\begin{array}{l}-0.54^{[30]} \\
(0.039)\end{array}$ & - & $-0.17^{[30]}$ \\
\hline $\mathrm{Ti}$ & $0.055^{[46]}$ & $-0.025^{[30]}$ & $-0.043^{[30]}$ & $0.024^{[30]}$ & $\begin{array}{l}0.042^{[30]} \\
(-0.001)\end{array}$ & $-2.04^{[35]}$ & $-1.8^{[46]}$ \\
\hline $\mathrm{N}$ & $\begin{array}{l}-0.047^{[46]} \\
(-0.0004)\end{array}$ & $0.049^{[44]}$ & $-0.02^{[35]}$ & $0.017^{[42]}$ & $-0.593^{[35]}$ & $0^{[43]}$ & $0.05^{[35]}$ \\
\hline
\end{tabular}

() second-order interaction parameters.

$$
\begin{gathered}
\frac{1}{2} \mathrm{O}_{2}(\mathrm{~g})=[\mathrm{O}] \\
\log K_{[1]}=\log \left[\frac{f_{o} \cdot[\operatorname{pct} \mathrm{O}]}{p_{\mathrm{O}_{2}}^{1 / 2}}\right]=\frac{6120}{T}+0.18 \\
\lg f_{i}=\sum\left(e_{i}^{j}[\operatorname{pct} j]+r_{i}^{j}[\operatorname{pct} j]^{2}\right),
\end{gathered}
$$

where [pct $j$ ] denotes the concentration of component $j$ in steel [mass pct], $f_{o}$ is the activity coefficient of $\mathrm{O}$ calculated based on Wagner Eq. [3] using the first- $\left(e_{i}^{j}\right)$ and second-order $\left(r_{i}^{j}\right)$ interaction parameters presented in Table IV.

Based on the discussions above, $\mathrm{TiO}_{x}-\mathrm{Cr}_{2} \mathrm{O}_{3}-\mathrm{Al}_{2} \mathrm{O}_{3}$, $\mathrm{TiO}_{x}-\mathrm{Cr}_{2} \mathrm{O}_{3}-\mathrm{SiO}_{2}, \mathrm{TiO}_{x}-\mathrm{Al}_{2} \mathrm{O}_{3}-\mathrm{MgO}$ system inclusions were found after $\mathrm{FeCr}$ additions. To quantitatively investigate the composition of these inclusions, the ratio of $\left(\right.$ mass $\left.\mathrm{Ti}_{2} \mathrm{O}_{3}\right) /\left(\right.$ mass $\mathrm{Ti}_{2} \mathrm{O}_{3}+$ mass $\left.\mathrm{TiO}_{2}\right)$ in the liquid phase has also been calculated by FactSage 7.1 with the databases of FToxid and FactPS and the results are shown in Figure 5. As can be seen, the ratio of (mass $\mathrm{Ti}_{2} \mathrm{O}_{3}$ ) to (mass $\mathrm{Ti}_{2} \mathrm{O}_{3}+$ mass $\mathrm{TiO}_{2}$ ) slightly decreases and then increases by increasing the mass $\mathrm{Cr}_{2} \mathrm{O}_{3}$ content regardless of the $\mathrm{Al}_{2} \mathrm{O}_{3}$ content in the $\mathrm{TiO}_{x}$ $\mathrm{Cr}_{2} \mathrm{O}_{3}-\mathrm{Al}_{2} \mathrm{O}_{3}$ system (Figure 5(a)). It should be pointed out that the $\mathrm{Cr}_{2} \mathrm{O}_{3}$ content corresponding to the lowest point gradually decreases with an increased $\mathrm{Al}_{2} \mathrm{O}_{3}$ content. The corresponding $\mathrm{Cr}_{2} \mathrm{O}_{3}$ content range smaller than this lowest point belongs to the $\mathrm{Ti}_{2} \mathrm{O}_{3}+$ liquid region where $\mathrm{Ti}_{2} \mathrm{O}_{3}$ is the main phase, as shown in Figure 4(f). Similarly, the ratios of (mass $\mathrm{Ti}_{2} \mathrm{O}_{3}$ ) to (mass $\mathrm{Ti}_{2} \mathrm{O}_{3}+$ mass $\mathrm{TiO}_{2}$ ) vary with the increase of $\mathrm{SiO}_{2}$ and $\mathrm{Al}_{2} \mathrm{O}_{3}$ contents in $\mathrm{TiO}_{x}-\mathrm{Cr}_{2} \mathrm{O}_{3}-\mathrm{SiO}_{2}$ system (Figure 5(b)) and $\mathrm{TiO}_{x}-\mathrm{Al}_{2} \mathrm{O}_{3}-\mathrm{MgO}$ system (Figure 5(c)), respectively.

Nevertheless, these ratios are not less than about 0.75 based on these calculations. Therefore, it can be concluded that the relative amount of $\mathrm{Ti}_{2} \mathrm{O}_{3}$ would be more dominant than that of $\mathrm{TiO}_{2}$ in these ternary systems at $1873 \mathrm{~K}\left(1600{ }^{\circ} \mathrm{C}\right)$ and $p\left(\mathrm{O}_{2}\right)=10^{-15} \mathrm{~atm}$. Park et al. ${ }^{[30]}$ also reported that the $\mathrm{Ti}_{2} \mathrm{O}_{3}$ phase was the dominant phase in $\mathrm{TiO}_{x}$ of the $\mathrm{TiO}_{x}-\mathrm{Al}_{2} \mathrm{O}_{3}-\mathrm{MgO}$ system inclusions at $p\left(\mathrm{O}_{2}\right)=10^{-13} \mathrm{~atm}$.
The compositions of different types of oxide inclusions are plotted on the $\mathrm{Ti}_{2} \mathrm{O}_{3}-\mathrm{Al}_{2} \mathrm{O}_{3}-\mathrm{MgO}, \mathrm{Ti}_{2} \mathrm{O}_{3}-$ $\mathrm{Cr}_{2} \mathrm{O}_{3}-\mathrm{SiO}_{2}$ and $\mathrm{Ti}_{2} \mathrm{O}_{3}-\mathrm{Cr}_{2} \mathrm{O}_{3}-\mathrm{Al}_{2} \mathrm{O}_{3}$ ternary phase diagrams, which were computed using FactSage 7.1 program with the FactPS and FToxid databases at 1873 $\mathrm{K}\left(1600^{\circ} \mathrm{C}\right)$ and $p\left(\mathrm{O}_{2}\right)=10^{-15}$ atm. The inclusions were mainly $\mathrm{Ti}_{2} \mathrm{O}_{3}$ and $\mathrm{Ti}_{2} \mathrm{O}_{3}-\mathrm{Al}_{2} \mathrm{O}_{3}$ systems before $\mathrm{FeCr}$ addition (S1), as shown in Figure 6(a). In addition, some $\mathrm{Ti}_{2} \mathrm{O}_{3}-\mathrm{Al}_{2} \mathrm{O}_{3}-\mathrm{MgO}$ inclusions were also observed and they were located in the liquid + spinel region. It can be seen that this type of inclusions was found in all the samples and the $\mathrm{Ti}_{2} \mathrm{O}_{3}$ contents in these inclusions slightly increased after $\mathrm{FeCr}$ addition. After 3 minutes from adding the $\mathrm{FeCr}$ alloy (S2), the main type of inclusions was found to belong to the $\mathrm{Ti}_{2} \mathrm{O}_{3}-$ $\mathrm{Cr}_{2} \mathrm{O}_{3}-\mathrm{Al}_{2} \mathrm{O}_{3}$ systems, where less than 5 pet $\mathrm{MnO}$ content was ignored. The last group of inclusions consisted of $\mathrm{Ti}_{2} \mathrm{O}_{3}-\mathrm{Cr}_{2} \mathrm{O}_{3}-\mathrm{SiO}_{2}$, and they are mostly located in the single liquid phase region, as shown in Figure 6(b). Also, almost all this type of inclusions are located in the same liquid region in the other samples, which contain $\mathrm{SiO}_{2}$ contents ranging from 10 to 60 mass pct. This explains the spherical shape of these inclusions.

In terms of the $\mathrm{Ti}_{2} \mathrm{O}_{3}-\mathrm{Cr}_{2} \mathrm{O}_{3}-\mathrm{Al}_{2} \mathrm{O}_{3}$ inclusions, the majority of inclusions are located in the liquid region (Figure 6(c)), which are more likely to correspond to those spherical inclusions as shown in Figure 3(j). Besides, some of them are located in the $\mathrm{Ti}_{2} \mathrm{O}_{3}+$ liquid region, which shows a good agreement with their irregular morphology. After 8 minutes from $\mathrm{FeCr}$ addition (S3), the number of inclusions (177 \#/mm²) significantly increases compared to that found in sample $\mathrm{S} 2$ taken at 3 minutes $\left(76 \# / \mathrm{mm}^{2}\right)$. It should be pointed out that the majority of inclusions are located in the $\mathrm{Ti}_{2} \mathrm{O}_{3}+$ liquid region. The composition distributions in the samples S4 (18 minutes) and S5 (30 minutes) do not show a significant difference, and inclusions containing high $\mathrm{Ti}_{2} \mathrm{O}_{3}$ (> 75 mass pet) contents still exist. These $\mathrm{Ti}_{2} \mathrm{O}_{3}$-rich solid inclusions can lead to the formation of submerged nozzle clogging problems or skin laminations or line defects on the rolled strip, which can severely impact the steel quality. ${ }^{[4]}$

The effect of $\mathrm{FeCr}$ addition on the average composition of $\mathrm{Ti}_{2} \mathrm{O}_{3}-\mathrm{Cr}_{2} \mathrm{O}_{3}-\mathrm{Al}_{2} \mathrm{O}_{3}$ system inclusions is shown in Figure 7(a). It can be seen that the average $\mathrm{Ti}_{2} \mathrm{O}_{3}$ content increases from about 62 mass pet in $\mathrm{S} 2$ to 72 mass pet in $\mathrm{S} 3$, while the $\mathrm{Cr}_{2} \mathrm{O}_{3}$ and $\mathrm{Al}_{2} \mathrm{O}_{3}$ contents slightly decrease. In sample $\mathrm{S} 2$, the average composition of $\mathrm{Ti}_{2} \mathrm{O}_{3}-\mathrm{Cr}_{2} \mathrm{O}_{3}-\mathrm{Al}_{2} \mathrm{O}_{3}$ inclusions is located in the single 


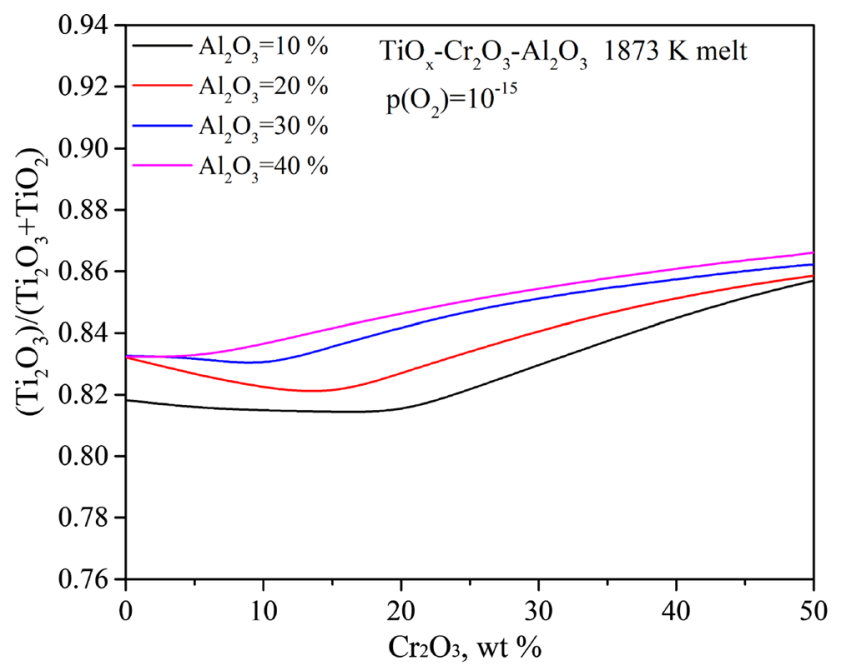

(a)

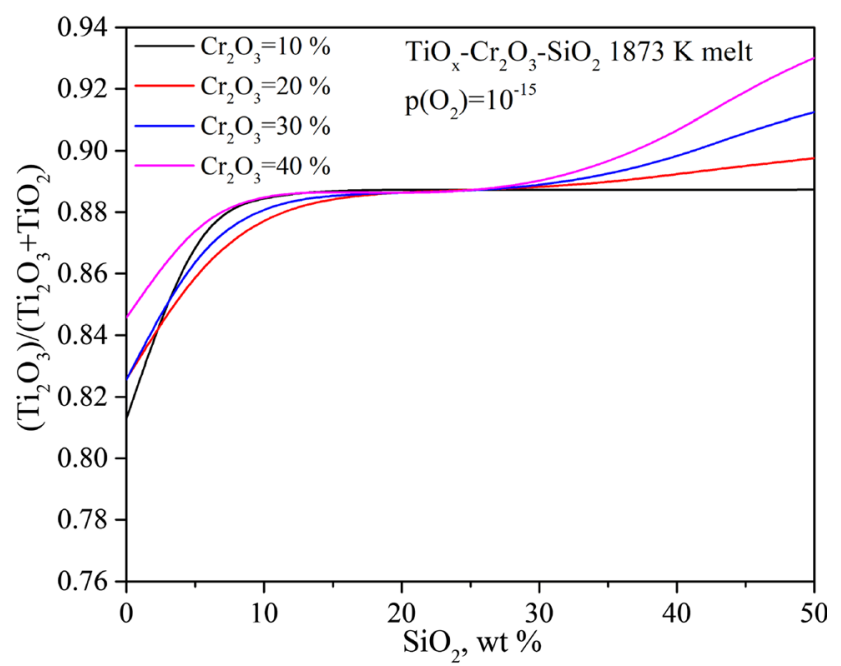

(b)

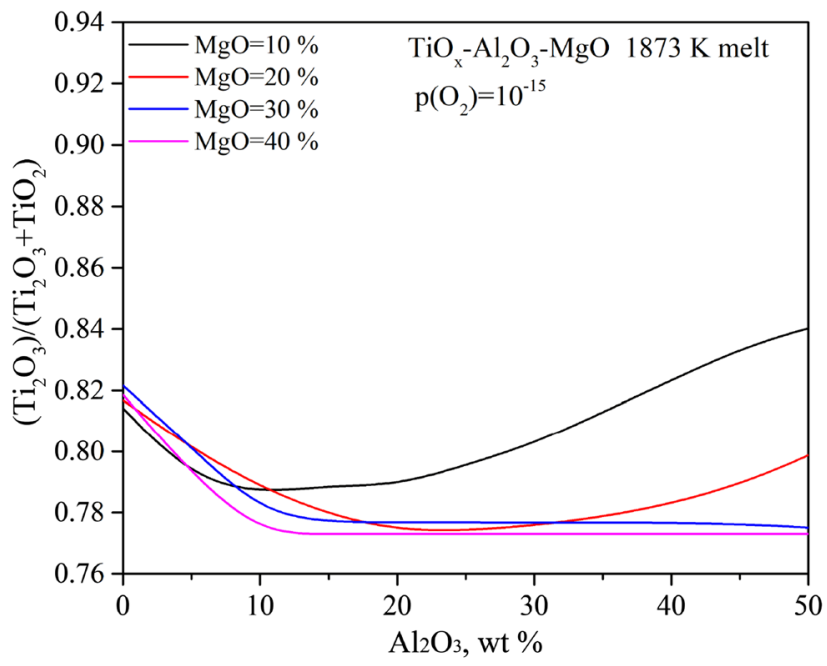

(c)

Fig. 5-The computed ratio of (mass $\mathrm{Ti}_{2} \mathrm{O}_{3}$ ) to (mass $\mathrm{Ti}_{2} \mathrm{O}_{3}+$ mass $\mathrm{TiO}_{2}$ ) in the liquid phase of the $(a) \mathrm{TiO}_{x}-\mathrm{Cr}_{2} \mathrm{O}_{3}-\mathrm{Al}_{2} \mathrm{O}_{3}$, $(b$ ) $\mathrm{TiO}_{x}-\mathrm{Cr}_{2} \mathrm{O}_{3}-\mathrm{SiO}_{2}$, and $(c) \mathrm{TiO}_{x}-\mathrm{Al}_{2} \mathrm{O}_{3}-\mathrm{MgO}$ inclusion systems at $1873 \mathrm{~K}\left(1600{ }^{\circ} \mathrm{C}\right)$ and $p\left(\mathrm{O}_{2}\right)=10^{-15} \mathrm{~atm}$.

liquid phase region. However, the average composition of the inclusions in sample $\mathrm{S} 3$ moves to the $\mathrm{Ti}_{2} \mathrm{O}_{3}+$ liquid region. It indicates that the fraction of high $\mathrm{Ti}_{2} \mathrm{O}_{3}$-containing inclusions increases during this period. Thereafter, the $\mathrm{Ti}_{2} \mathrm{O}_{3}$ content decreases to 67 mass pct in $\mathrm{S} 4$ and 63 mass pct in S5. Meanwhile, the average $\mathrm{Al}_{2} \mathrm{O}_{3}$ and $\mathrm{Cr}_{2} \mathrm{O}_{3}$ contents slightly increase, and the average compositions of $\mathrm{Ti}_{2} \mathrm{O}_{3}-\mathrm{Cr}_{2} \mathrm{O}_{3}-\mathrm{Al}_{2} \mathrm{O}_{3}$ inclusions move back to the liquid region. According to the above discussions, some high $\mathrm{Ti}_{2} \mathrm{O}_{3}$ solid inclusions can form clusters due to the agglomeration and thereafter they easily float up from the melt.

The average size change of different types of inclusions are presented in Figure 7(b). It can be seen that the average size of $\mathrm{Ti}_{2} \mathrm{O}_{3}-\mathrm{Cr}_{2} \mathrm{O}_{3}-\mathrm{Al}_{2} \mathrm{O}_{3}$ inclusions first slightly increases and then decreases. It should be pointed out that many clusters containing high $\mathrm{Ti}_{2} \mathrm{O}_{3}$ contents were observed in the three-dimensional extracted samples, but few large size inclusions were detected when using the two-dimensional automatic SEM analysis. Relatively larger sizes of $\mathrm{Ti}_{2} \mathrm{O}_{3}-\mathrm{Cr}_{2} \mathrm{O}_{3}-\mathrm{SiO}_{2}$ inclusions were observed compared to the other types of inclusions, which might be due to the fact that they were mostly liquid as shown in Figure 6(b) and therefore easier to collide and grow. While for $\mathrm{Ti}_{2} \mathrm{O}_{3}-\mathrm{Al}_{2} \mathrm{O}_{3}-\mathrm{MgO}$ inclusions, they keep at a stable level of about $2.2( \pm 0.5) \mu \mathrm{m}$ during the experiment. In terms of TiN inclusions, they have the largest sizes in sample S1 and decrease from $\mathrm{S} 1$ to $\mathrm{S} 3$ and then slightly increases from $\mathrm{S} 3$ to S5. The size distributions of TiN inclusions in this steel grade are studied elsewhere, the results showed that most of the TiN inclusions were smaller than 1 $\mu \mathrm{m} .{ }^{[5]}$ However, these fine inclusions were not detected and counted in the present study due to the automatic SEM detection limit. Therefore, the size measurements of the TiN inclusions can only partially reflect the real situations. 


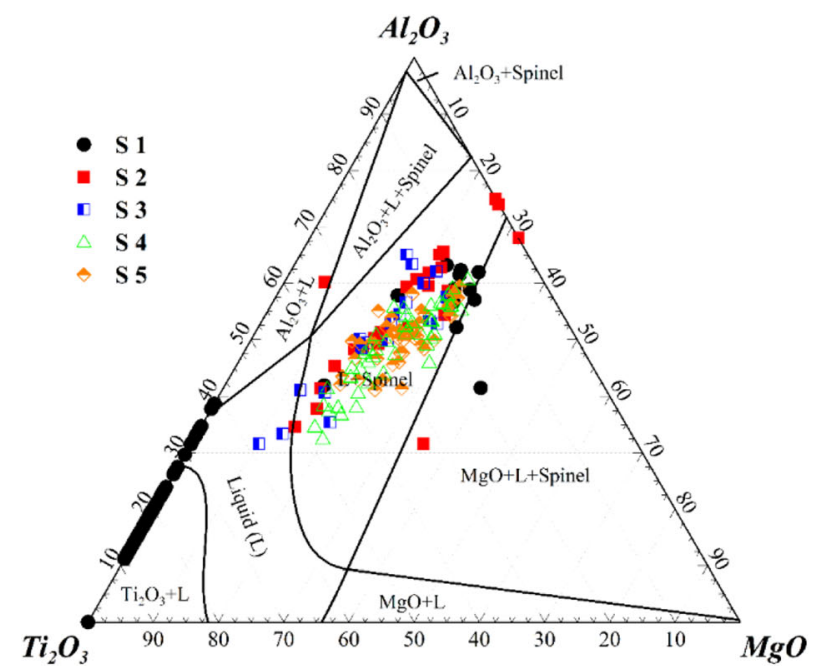

(a)

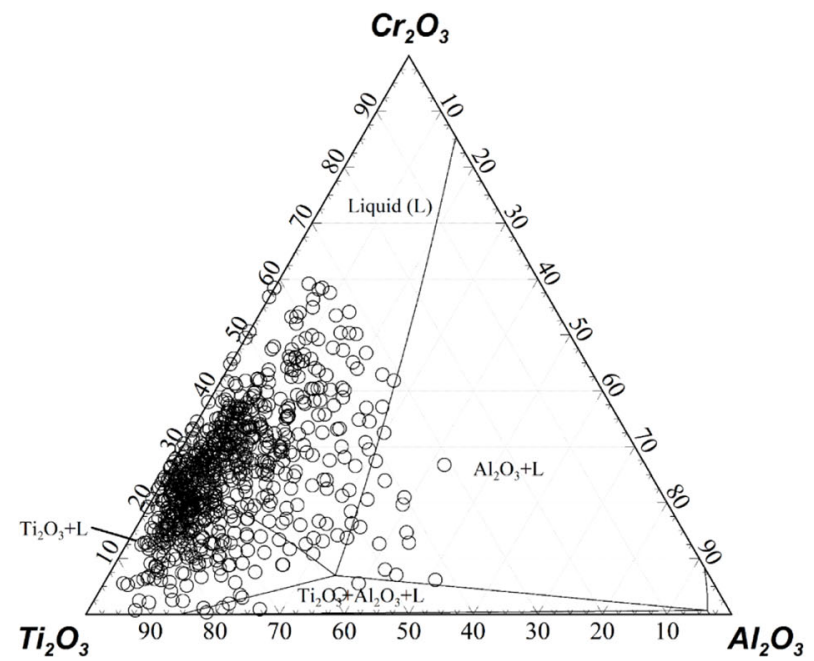

(c) $\mathrm{S} 2(3 \mathrm{~min})$

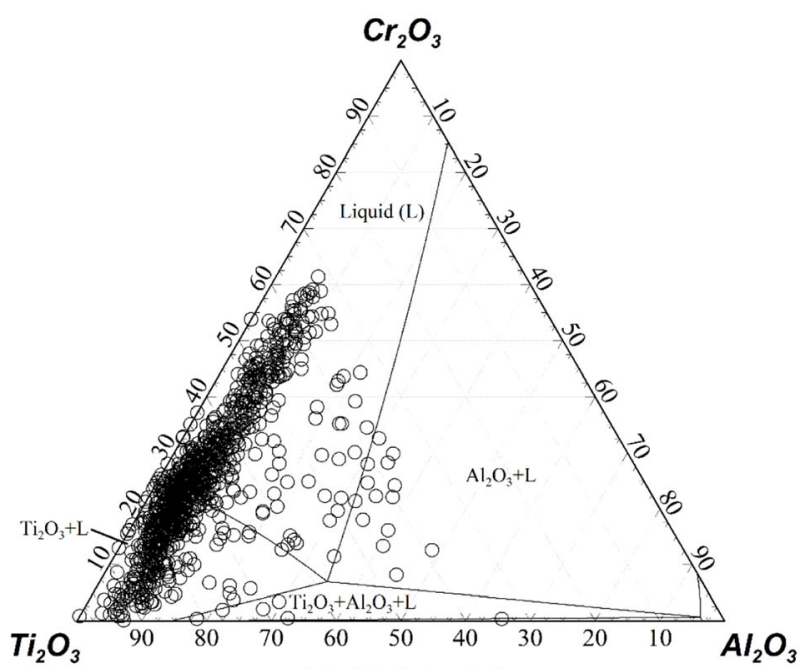

(e) $\mathrm{S} 4(18 \mathrm{~min})$

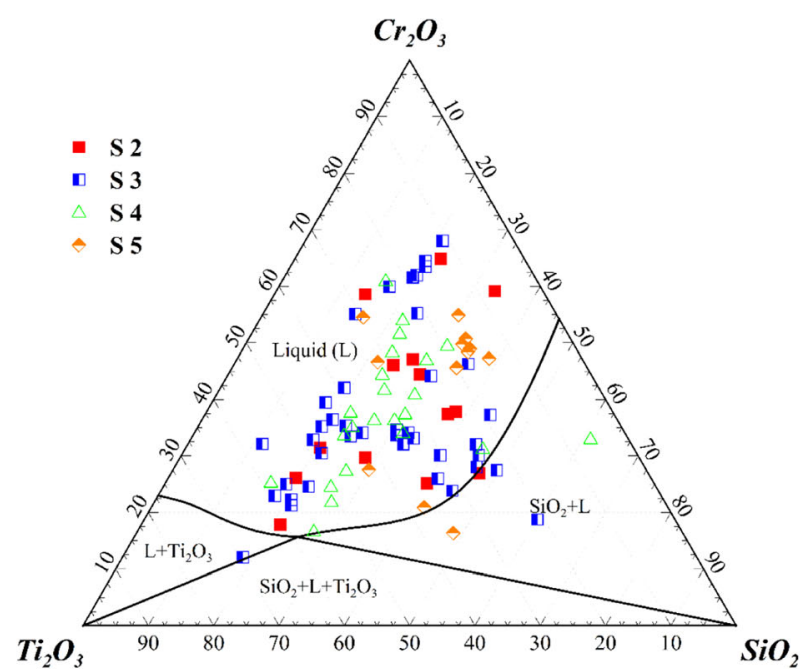

(b)

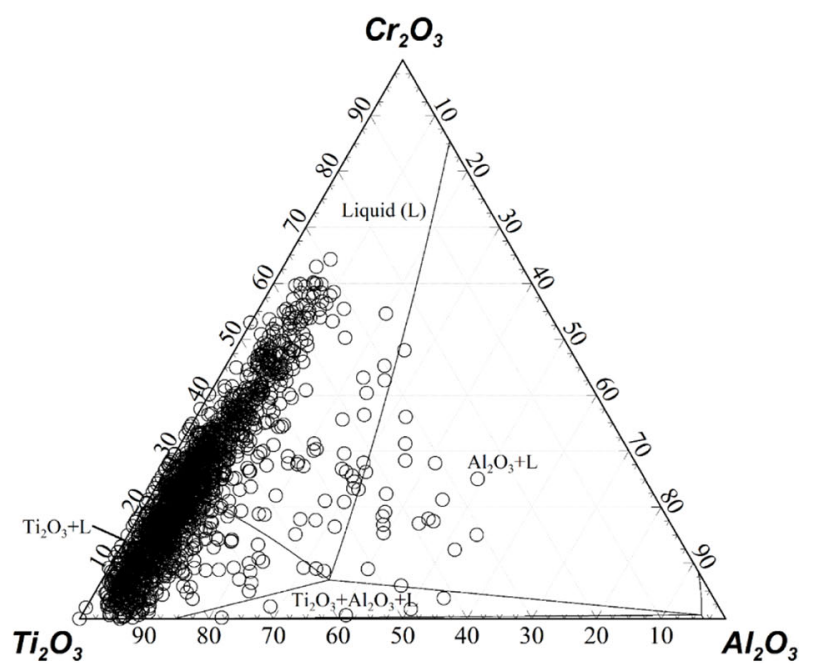

(d) $\mathrm{S} 3$ (8 $\mathrm{min})$

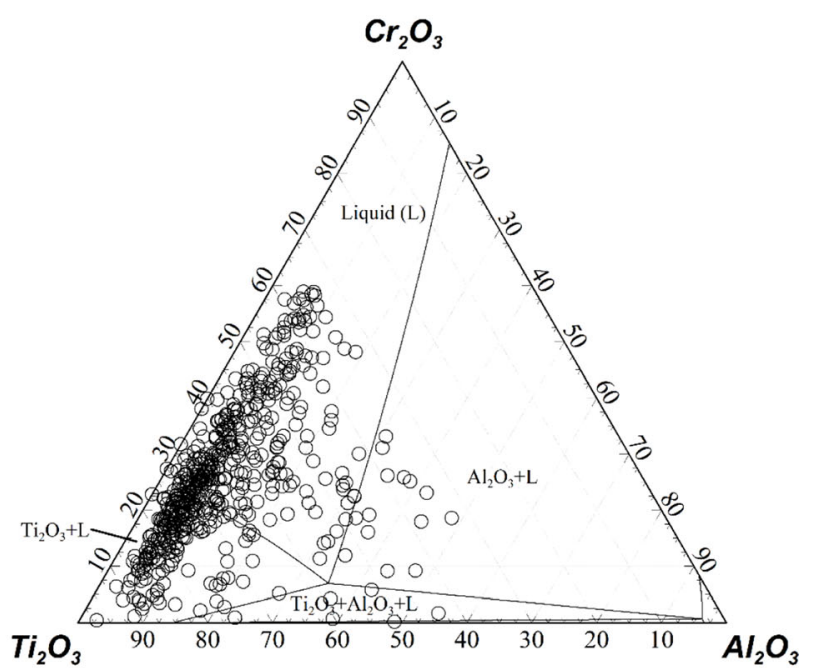

(f) $\mathrm{S} 5$ (30 $\mathrm{min})$

Fig. 6-Evolution of inclusions with the addition of $\mathrm{FeCr}$ alloys: (a) $\mathrm{Ti}_{2} \mathrm{O}_{3}-\mathrm{Al}_{2} \mathrm{O}_{3}-\mathrm{MgO}$ inclusions in $\mathrm{S} 1$ to $\mathrm{S} 5,\left(\right.$ b) $\mathrm{Ti}_{2} \mathrm{O}_{3}-\mathrm{Cr}_{2} \mathrm{O}_{3}-\mathrm{SiO}_{2}$ inclusions in $\mathrm{S} 2$ to $\mathrm{S} 5, \mathrm{Ti}_{2} \mathrm{O}_{3}-\mathrm{Cr}_{2} \mathrm{O}_{3}-\mathrm{Al}_{2} \mathrm{O}_{3}$ inclusions in (c) $\mathrm{S} 2,(d) \mathrm{S} 3,(e) \mathrm{S} 4$, and $(f) \mathrm{S} 5$. 


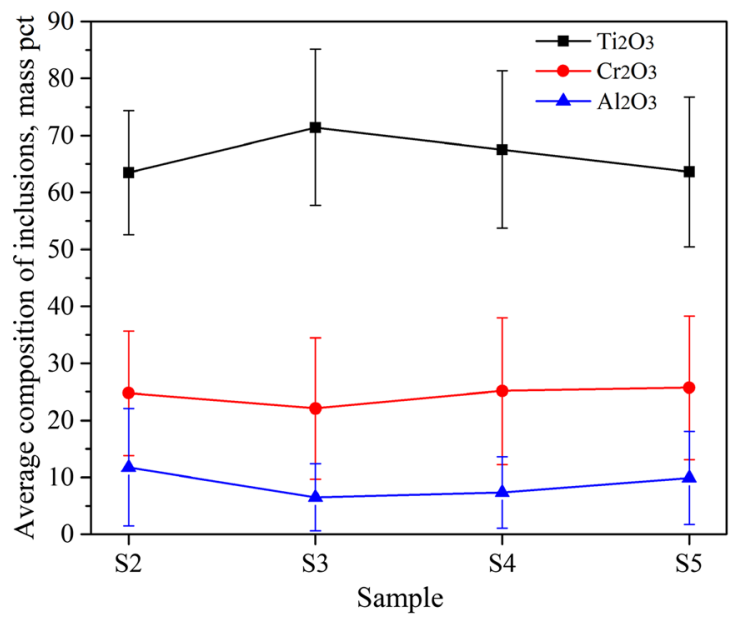

(a)

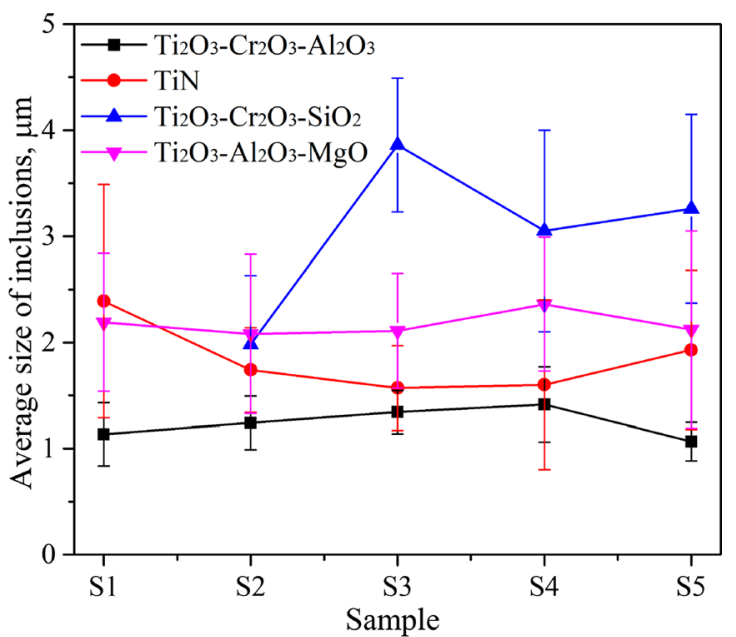

(b)

Fig. 7-Average composition changes of $\mathrm{Ti}_{2} \mathrm{O}_{3}-\mathrm{Cr}_{2} \mathrm{O}_{3}-\mathrm{Al}_{2} \mathrm{O}_{3}$ inclusions $(a)$ and the average size of different types of inclusions $(b)$.

The fraction of each inclusion type in different samples and the number density of $\mathrm{Ti}_{2} \mathrm{O}_{3}-\mathrm{Cr}_{2} \mathrm{O}_{3}-\mathrm{Al}_{2} \mathrm{O}_{3}$ and $\mathrm{TiN}$ inclusions are presented in Figure 8. It should be noted that $\mathrm{Ti}_{2} \mathrm{O}_{3}-\mathrm{Cr}_{2} \mathrm{O}_{3}-\mathrm{Al}_{2} \mathrm{O}_{3}$ inclusions in $\mathrm{S} 1 \mathrm{refer}$ to $\mathrm{Ti}_{2} \mathrm{O}_{3}$ and $\mathrm{Ti}_{2} \mathrm{O}_{3}-\mathrm{Al}_{2} \mathrm{O}_{3}$ inclusions, which correspond to two main types of inclusions in Figures 3(b) and (c). It can be seen that the majority of the inclusions in S1 (before $\mathrm{FeCr}$ addition) are $\mathrm{TiN}$ inclusions, which accounts for approximately 70 pct of the total inclusions. After the addition of $\mathrm{FeCr}$ alloys, the fraction of TiN inclusions decreases significantly in samples S2 (3 minutes) and S3 (8 minutes). Thereafter, the amount remains at a small level of less than 5 pct in samples $\mathrm{S} 4$ (18 minutes) and $\mathrm{S} 5$ (30 minutes).

Meanwhile, the fraction of $\mathrm{Ti}_{2} \mathrm{O}_{3}-\mathrm{Cr}_{2} \mathrm{O}_{3}-\mathrm{Al}_{2} \mathrm{O}_{3}$ inclusions increases with time and becomes the major part of inclusions in the final sample S5 (>80 pct). It should be pointed out that some MnO-containing inclusions (the $\mathrm{MnO}$ contents vary from 6 mass pet to 33 mass pet) were only observed after a short time from $\mathrm{FeCr}$ addition (S2). Also, their sizes are much smaller compared to those of the $\mathrm{MnCr}_{2} \mathrm{O}_{4}$ inclusions. This means that most $\mathrm{MnCr}_{2} \mathrm{O}_{4}$ inclusions started to transform during this period. $\mathrm{Ti}_{2} \mathrm{O}_{3}-\mathrm{Al}_{2} \mathrm{O}_{3}-\mathrm{MgO}$ inclusions were observed in all samples, and their fraction was slightly larger in samples $\mathrm{S} 4$ and $\mathrm{S} 5$ compared to the other samples. The $\mathrm{Ti}_{2} \mathrm{O}_{3}-\mathrm{Cr}_{2} \mathrm{O}_{3}-\mathrm{SiO}_{2}$ inclusions were generated in sample $\mathrm{S} 2$ after $\mathrm{FeCr}$ addition and their fraction slightly increased in sample S3 and then remained at a similar level.

When it comes to the number density of $\mathrm{Ti}_{2} \mathrm{O}_{3}$ $\mathrm{Cr}_{2} \mathrm{O}_{3}-\mathrm{Al}_{2} \mathrm{O}_{3}$ inclusions, it greatly increases from sample $\mathrm{S} 1$ to $\mathrm{S} 3$ and reaches a maximum value in $\mathrm{S} 3$ after $\mathrm{FeCr}$ addition. Then, their number density is reduced due to the inclusion floatation. The number density of TiN inclusions shows a decreasing tendency with time except for small fluctuations and reaches a much smaller number density value in S5 compared to S1. Although the majority of the TiN inclusions have an average size smaller than $1 \mu \mathrm{m}$, which could not be detected here, their numbers significantly decreased based on the experimental results of the extracted samples.

\section{Thermodynamic Calculations of Inclusion Transformations}

\section{TiN solubility in the steel melt}

Figure 9 shows the TiN and oxide inclusion formations in different samples based on the compositions in Figure 2 calculated using the Scheil-Gulliver model in FactSage 7.1 with the FSstel and FToxid databases. Also, the calculated liquidus $\left(T_{\mathrm{s}}\right)$ and solidus $\left(T_{\mathrm{L}}\right)$ temperatures of steel containing 24 mass pct $\mathrm{Cr}$ are $1767 \mathrm{~K}$ and $1780 \mathrm{~K}\left(1494{ }^{\circ} \mathrm{C}\right.$ and $\left.1507{ }^{\circ} \mathrm{C}\right)$, respectively. As can be seen from Figure 9(a) the TiN inclusions form in the mushy zone of the solidifying steel for all samples. The formation temperatures of the TiN inclusions can vary depending on the different $\mathrm{Ti}$ and $\mathrm{N}$ contents in the steel melt. However, their precipitation temperature does not change much based on the calculation results. It should be pointed out that the calculations can predict the relative amount of TiN inclusions in different samples. The amount of TiN inclusions reached a maximum value after 8 minutes of $\mathrm{FeCr}$ alloy addition and then decreased to a lower level than that in the sample before $\mathrm{FeCr}$ addition. In terms of the oxide inclusions in Figure 9(b), the main oxide inclusions were ilmenite $\left(\mathrm{Ti}_{2} \mathrm{O}_{3}\right)$ and liquid inclusions $\left(\mathrm{TiO}_{x}>80 \mathrm{pct}\right)$, where the $\mathrm{Ti}_{2} \mathrm{O}_{3}$ inclusions precipitated after liquid inclusions in all samples. In sample $\mathrm{S} 1$, the amount of $\mathrm{Ti}_{2} \mathrm{O}_{3}$ inclusions was a little higher than that of liquid inclusions. However, the amount of liquid inclusions greatly increased in sample $\mathrm{S} 3$, and the value became three times higher than that of $\mathrm{Ti}_{2} \mathrm{O}_{3}$ inclusions. In the final sample $\mathrm{S} 5$, the amount of both liquid and $\mathrm{Ti}_{2} \mathrm{O}_{3}$ inclusions decreased a lot but were still higher than those in sample S1. These predicted results are in a good agreement with the experimental results. 


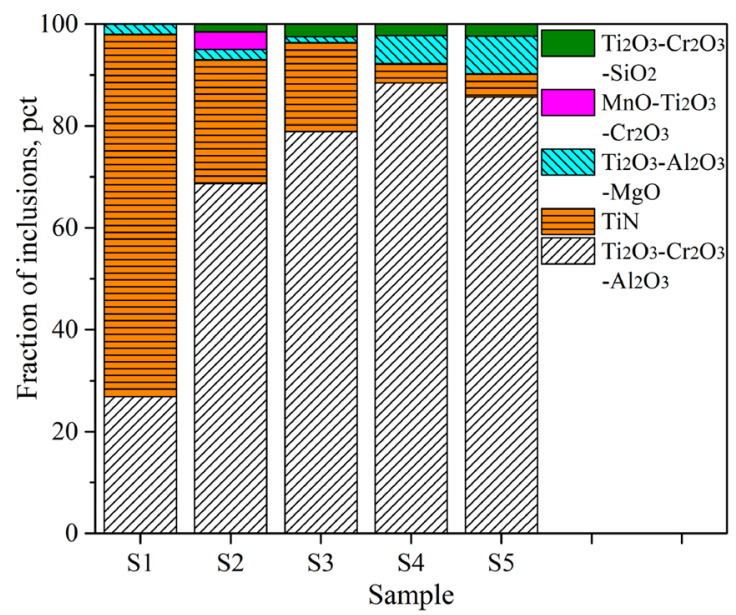

(a)

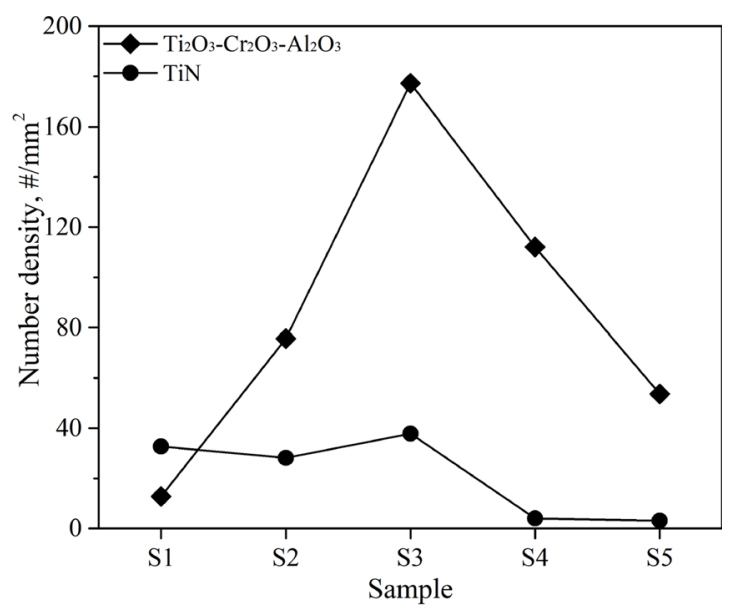

(b)

Fig. 8 - Change in the relative fraction of different types of inclusions (a) and number density of $\mathrm{Ti}_{2} \mathrm{O}_{3}-\mathrm{Cr}_{2} \mathrm{O}_{3}-\mathrm{Al}_{2} \mathrm{O}_{3}$ and $\mathrm{TiN}$ inclusions $(b)$.

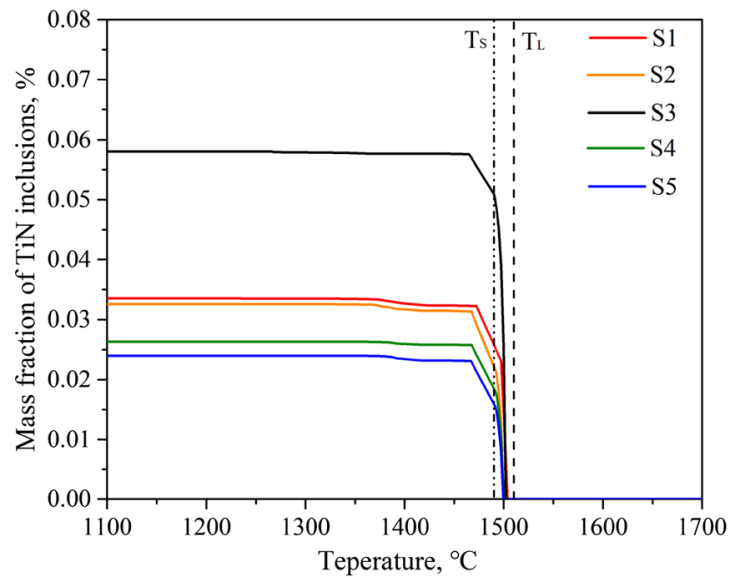

(a)

Fig. 9-Predicted TiN $(a)$ and oxide inclusions $(b)$ in different samples.

The reaction equilibrium for the formation of TiN inclusions in liquid steel can be written as follows ${ }^{[48]}$.

$$
[T i]+[N]=\operatorname{TiN}_{(s)} \quad \Delta G^{\theta}=-302200+107.8 T \mathrm{~J} / \mathrm{mol}
$$

$$
\Delta G=\Delta G^{\theta}+R T \ln \frac{a_{T i N}}{f_{\mathrm{Ti}} f_{\mathrm{N}}[\mathrm{pct} \mathrm{Ti}][\mathrm{pct} \mathrm{N}]},
$$

where $a_{\mathrm{TiN}}$ is the activity of TiN, under the current experimental conditions, the activity of TiN is unit. $f_{\mathrm{Ti}}$, $f_{\mathrm{N}}$ are the activity coefficients of $\mathrm{Ti}$ and $\mathrm{N}$ which are calculated using the classical Wagner formalism Eq. [9] with the first- and second-order interaction parameters that are listed in Table III. [pct Ti] and [pct N] are the mass concentrations of $\mathrm{Ti}$ and $\mathrm{N}$ in molten steel, respectively.

The contours of the solubility product TiN in the steel melt at $1873 \mathrm{~K}\left(1600{ }^{\circ} \mathrm{C}\right)$ for two different $\mathrm{Cr}$ contents (16 and 24 mass pct $\mathrm{Cr}$ before and after $\mathrm{FeCr}$ addition, respectively) and different temperatures are shown in

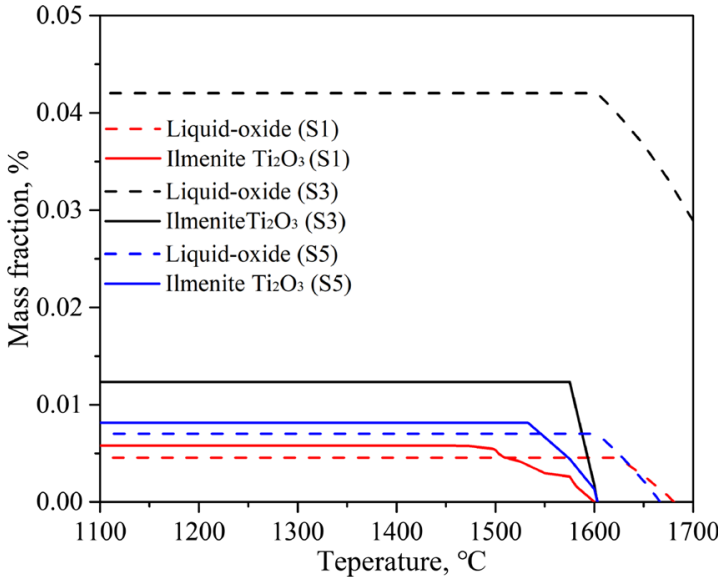

(b)

Figure 10. The measured $\mathrm{Ti}$ and $\mathrm{N}$ contents in different steel samples are also shown in the diagram (solid symbol). It is interesting to note that as the $\mathrm{Cr}$ content increases in liquid steel, the critical $\mathrm{N}$ content to form TiN inclusions increases at a specific $\mathrm{Ti}$ content. It means that an increased $\mathrm{Cr}$ content is not favorable for the formation of TiN inclusions in the steel melt. Moreover, the critical $\mathrm{N}$ and $\mathrm{Ti}$ contents decrease significantly as the temperature decreases. This was also reported for $\mathrm{TiN}^{[49]}$ and $\mathrm{AlN}^{[50,51]}$ inclusions in the previous works.

TiN was predicted not to form at $1873 \mathrm{~K}\left(1600{ }^{\circ} \mathrm{C}\right)$, i.e., the experimental temperature in $\mathrm{S} 1$ because the melt composition was located below the TiN saturation curve. Hence, the TiN inclusions were not saturated before $\mathrm{FeCr}$ addition. In sample $\mathrm{S} 2$ after the $\mathrm{FeCr}$ alloy addition, the $\mathrm{N}$ content slightly increased and reached a maximum value in sample S3. It was reported that the nitrogen solubility increased significantly while the titanium content decreased with an increased $\mathrm{Cr}$ content. ${ }^{[49]}$ The effect of $\mathrm{Cr}$ on the solubility product of $\mathrm{TiN}$ was primarily the result of the effect of $\mathrm{Cr}$ on the 


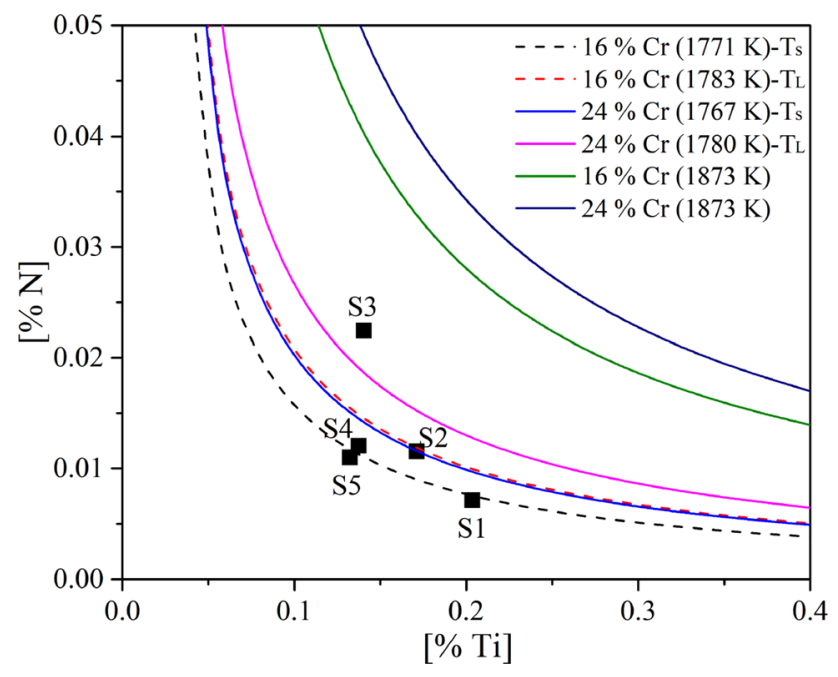

Fig. 10-TiN solubility diagram at different temperatures.

solubility of $\mathrm{N}$ in the melt due to the different interaction parameters for $\mathrm{Cr}$ to $\mathrm{Ti}(0.024)$, and $\mathrm{Cr}$ to $\mathrm{N}(-0.06)$. In $\mathrm{S} 3$, TiN inclusions can form above the liquidus temperature, which was still below the saturation curve of 1873 $\mathrm{K}\left(1600{ }^{\circ} \mathrm{C}\right)$. In samples S4 and S5, the experimental points were located below the saturation curve of the solidus temperature $\left(1767 \mathrm{~K}, 1494^{\circ} \mathrm{C}\right)$.

Theoretically, TiN inclusions could form in steel samples due to local cooling conditions. Based on the FactSage adiabatic temperature calculation by setting $\Delta \mathrm{H}=0$, the final temperature of $500 \mathrm{~g}$ steel $(1873 \mathrm{~K}$, $\left.1600{ }^{\circ} \mathrm{C}\right)$ and $85 \mathrm{~g} \mathrm{FeCr}\left(298 \mathrm{~K}, 25^{\circ} \mathrm{C}\right)$ are about $1777 \mathrm{~K}$ $\left(1504{ }^{\circ} \mathrm{C}\right)$. Even though this can be different from the real case, it indicates that the local temperature around $\mathrm{FeCr}$ alloy lumps $(0.5 \mathrm{~mm}$ at average size) could drop after alloy addition. Therefore, TiN inclusions could form as a result of a local temperature decrease. Moreover, a strong agitation of the melt by inductive stirring resulted in a fast attainment of the equilibrium nitrogen and titanium solubility for TiN saturation. In samples $\mathrm{S} 4$ and $\mathrm{S} 5$, the $\mathrm{N}$ content greatly decreased and as a result, the amount of TiN inclusions decreased during solidification.

\section{Evolution mechanism of the inclusions in steel}

To understand the transformation of inclusions in steel, a thermodynamic analysis was performed. According to the experimental findings, equilibrium calculations were made to simulate the inclusion evolution in steel. The calculations were carried out between $0.5 \mathrm{~g}$ $\mathrm{MnO}$ (32 mass pct)- $\mathrm{Cr}_{2} \mathrm{O}_{3}$ (68 mass pct) and $\times$ g TiN using the FactSage 7.1 software with databases of FactPS, FToxid, and FTstel. This calculation can present the possible reactions when TiN are formed initially after $\mathrm{FeCr}$ additions, the results are presented in Figure 11(a). As can be seen, with an increased fraction of TiN, the fraction of $\mathrm{MnCr}_{2} \mathrm{O}_{4}$ significantly decreases and liquid inclusions start to form. The fraction of liquid inclusions reaches a maximum value when the TiN fraction is about 14 pct of the total reactants. Then it starts to decrease with an increased TiN fraction and thereafter sharply decreases when the fraction of TiN is larger than 36 pet. Also, $\mathrm{Ti}_{2} \mathrm{O}_{3}$ (ilmenite) starts to form after this point. The liquid inclusions disappear when the TiN fraction is larger than 43 pct and pure TiN exists when the TiN fraction further increases.

The mass fraction changes of the different components in the liquid phase are shown in Figure 11(b). It can be clearly seen that $\mathrm{Cr}_{2} \mathrm{O}_{3}$ and $\mathrm{MnO}$ are the two major components in the liquid phase when the TiN fraction is less than 14 pct. Subsequently, the fractions of $\mathrm{MnO}$ and $\mathrm{TiO}_{2}$ start to decrease while that of $\mathrm{Ti}_{2} \mathrm{O}_{3}$ greatly increases. Also, the fraction of $\mathrm{Cr}_{2} \mathrm{O}_{3}$ decreases to some extent with an increased $\mathrm{TiN}$ fraction. These changes can be expressed by Eqs. [12] through [14]. Finally, the composition of the liquid phase is about 69 mass pet $\mathrm{Ti}_{2} \mathrm{O}_{3}$ and 31 mass pet $\mathrm{Cr}_{2} \mathrm{O}_{3}$ when the TiN fraction is larger than 36 pct. This composition is in good agreement with the composition of liquid $\mathrm{Ti}_{2} \mathrm{O}_{3}-$ $\mathrm{Cr}_{2} \mathrm{O}_{3}$ inclusions, as shown earlier in Figure 3(q).

$$
\begin{gathered}
\mathrm{TiN}=[T i]+[N] \\
x[\mathrm{Ti}]+y(\mathrm{MnO})=\left(\mathrm{Ti}_{x} \mathrm{O}_{y}\right)+y[\mathrm{Mn}] \\
x[\mathrm{Ti}]+\frac{z}{3}\left(\mathrm{Cr}_{2} O_{3}\right)=\left(\mathrm{Ti}_{x} \mathrm{O}_{z}\right)+\frac{2 z}{3}[\mathrm{Cr}] .
\end{gathered}
$$

Alternatively, the steel melt has relatively high $\mathrm{Ti}$ content ( 0.2 mass pct) and $\mathrm{Al}$ content ( 0.01 mass pct) before $\mathrm{FeCr}$ addition. Therefore, another possibility for an inclusion transformation to occur is due to a direct reaction of $\mathrm{MnCr}_{2} \mathrm{O}_{4}$ with $\mathrm{Ti}$ or $\mathrm{Al}$ in the melt. Simplified equilibrium calculations were carried out between $0.5 \mathrm{~g} \mathrm{MnO}$ (32 mass pct) $-\mathrm{Cr}_{2} \mathrm{O}_{3}$ (68 mass pct) and different $\mathrm{Ti}$ or $\mathrm{Al}$ contents ( 0 to 0.4 mass pet) using the FactSage 7.1 software with databases of FSstel and FToxid. The results are shown in Figure 12. It can be seen from Figure 12(a) that if the steel only contained $\mathrm{Al}$, the $\mathrm{MnCr}_{2} \mathrm{O}_{4}$ inclusions from the alloy can be reduced by $\mathrm{Al}$ and firstly form $\mathrm{MnAl}_{2} \mathrm{O}_{4}$ spinels and then transforms into $\mathrm{Al}_{2} \mathrm{O}_{3}$ with the increase of $\mathrm{Al}$ content. The $\mathrm{Cr}$ and $\mathrm{Mn}$ generated by the reductions will be present in the liquid Fe phase, which is not listed here. In Figure 12(b), if the steel only contained Ti, $\mathrm{MnCr}_{2} \mathrm{O}_{4}$ inclusions can react with Ti to form liquid inclusions. Thereafter, the amount of liquid inclusions decreases and $\mathrm{Ti}_{2} \mathrm{O}_{3}$ forms with an increased Ti content.

Both Ti and Al are present in the steel melt, so their combined effects need to be considered. In Figure 12(c), the Ti content is fixed as 0.2 mass pct, it can be clearly seen that the fraction of liquid inclusions decreases while that of $\mathrm{Ti}_{2} \mathrm{O}_{3}$ (ilmenite) increases when the $\mathrm{Al}$ content is less than 0.05 mass pct. Thereafter, pure $\mathrm{Al}_{2} \mathrm{O}_{3}$ starts to form and the fraction gradually increases while the fraction of $\mathrm{Ti}_{2} \mathrm{O}_{3}$ (ilmenite) decreases and disappears when the $\mathrm{Al}$ content is larger than 0.21 mass pct. A similar case can be seen in Figure 12(d) where the Al content is fixed as 0.01 mass pct. Al firstly reacts with $\mathrm{MnCr}_{2} \mathrm{O}_{4}$ inclusions to form $\mathrm{MnAl}_{2} \mathrm{O}_{4}$ spinels, but 


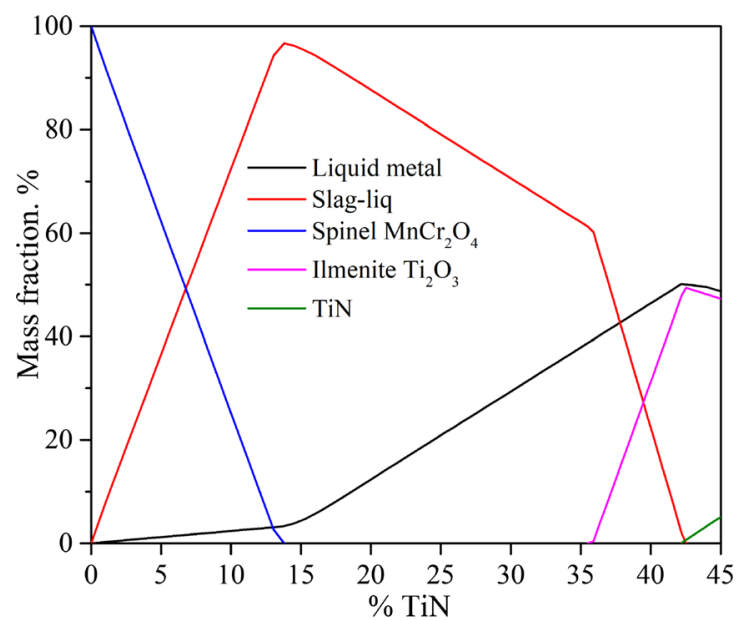

(a)

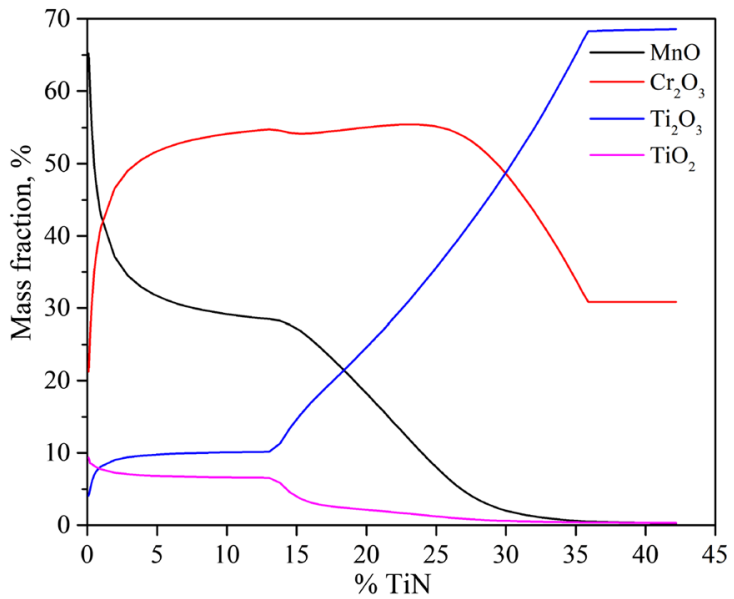

(b)

Fig. 11-Mass fractions of $(a)$ the different phases after the reaction between $\mathrm{MnCr}_{2} \mathrm{O}_{4}$ and $\mathrm{TiN}$ and $(b)$ different components in the liquid inclusions.

liquid inclusions are in majority when the Ti content is in the range of 0.1 to 0.2 mass pct. At the present steel compositions, $\mathrm{Ti}_{2} \mathrm{O}_{3}$ and liquid inclusions are the main types of inclusions. It should be pointed out that the liquid inclusions contain 10 to 35 mass pet $\mathrm{Al}_{2} \mathrm{O}_{3}$ when both $\mathrm{Al}$ and $\mathrm{Ti}$ are considered. However, from the experimental results, the average $\mathrm{Al}_{2} \mathrm{O}_{3}$ content in the inclusions is about 8 mass pct, which is much smaller than the calculated values. This suggests that the reaction between $\mathrm{Ti}$ and $\mathrm{MnCr}_{2} \mathrm{O}_{4}$ is more preferable compared with $\mathrm{Al}$ in the present study. The real situation in the melt might be more complex. However, one critical issue is the ratio of $\mathrm{Ti} / \mathrm{Al}$ in the melt, which can greatly affect the inclusion characteristics in Al-killed Ti-containing steels. ${ }^{[52]}$ A Further study of alloying experiments by considering different $\mathrm{Ti} / \mathrm{Al}$ ratios in the melt should be carried out.

Based on the preceding analysis, the possible inclusion evolution mechanism caused by $\mathrm{FeCr}$ additions are summarized in Figure 13. The dissolution and melting process of $\mathrm{FeCr}$ alloys contain several stages, the main stages are schematically shown here. When an alloy piece is dropped into the melt, a solid steel shell will form outside the alloy due to the temperature difference between the alloy piece and the steel melt. ${ }^{[20,53-55]} \mathrm{A}$ reaction zone between the alloy and steel shell will form, and the inclusions from the alloy can move or stay depending on the state of the reaction zone. Previous studies have reported this kind of phenomenon. ${ }^{[20,56,57]}$ Moreover, the temperature in the local area surrounding the alloy will decrease to a certain extent. As a result, TiN inclusions can form inside this area due to the increase of the supersaturation degree caused by the temperature drop. Then, as heat is continuously being supplied from the surrounding steel (by induction heating), the steel shell and the alloy melting process are accelerated. The inclusions from the alloy can freely move to the melt. Some big size inclusions will directly float up to the surface layer as well as adhere to the crucible wall. Furthermore, some inclusions can react with $\mathrm{TiN}$ or dissolved $\mathrm{Ti}$ to form $\mathrm{TiO}_{x}$-containing inclusions, where TiN inclusions are decomposed into dissolved titanium and nitrogen. Later, the whole alloy piece will melt and fewer TiN inclusions can be formed due to the increased temperature and smaller available $\mathrm{Ti}$ and $\mathrm{N}$ contents in the melt.

\section{CONCLUSIONS}

Alloying experiments using $\mathrm{FeCr}$ alloys have been performed in Ti-containing ferritic stainless steel. The evolution of inclusions in the steel melt was quantitatively analyzed to establish how the addition of $\mathrm{FeCr}$ alloys influence the inclusions in steel. The results of this study can be summarized as follows:

1. The main type of inclusions found in the investigated $\mathrm{FeCr}$ alloys is a polygonal $\mathrm{MnCr}_{2} \mathrm{O}_{4}$ spinel (73 pct) with size ranges of 3 to $72 \mu \mathrm{m}$. The other inclusion types are pure $\mathrm{Al}_{2} \mathrm{O}_{3}$ inclusions $(\sim 19 \mathrm{pct})$ and complex $\mathrm{Al}_{2} \mathrm{O}_{3}-\mathrm{SiO}_{2}-\mathrm{CaO}-\mathrm{MgO}$ inclusions ( $\left.~ 8 \mathrm{pct}\right)$.

2. After $\mathrm{FeCr}$ additions, $\mathrm{MnCr}_{2} \mathrm{O}_{4}$ spinel inclusions in the $\mathrm{FeCr}$ alloys were transformed into $\mathrm{Ti}_{2} \mathrm{O}_{3}-$ $\mathrm{Cr}_{2} \mathrm{O}_{3}$-based inclusions with a small amount of $\mathrm{Al}_{2} \mathrm{O}_{3}$. Their compositions are located in the single liquid and $\mathrm{Ti}_{2} \mathrm{O}_{3}+$ liquid regions. The number density of $\mathrm{Ti}_{2} \mathrm{O}_{3}-\mathrm{Cr}_{2} \mathrm{O}_{3}-\mathrm{Al}_{2} \mathrm{O}_{3}$ inclusions greatly increased with time and reached a maximum value after 8 minutes of $\mathrm{FeCr}$ addition. Also, high melting point $\mathrm{Ti}_{2} \mathrm{O}_{3}$-rich inclusions still existed in the final samples, and their number density was larger than that before the $\mathrm{FeCr}$ alloy addition, which certainly decreased the steel cleanliness.

3. The number density of TiN inclusions first increased and then significantly decreased to a much smaller level compared to that before $\mathrm{FeCr}$ addition. The critical $\mathrm{N}$ and $\mathrm{Ti}$ contents needed to form TiN inclusions increase with an increased $\mathrm{Cr}$ content in liquid steel. The TiN inclusions in the steel melt have the possibility to react with $\mathrm{MnCr}_{2} \mathrm{O}_{4}$ inclusions from 


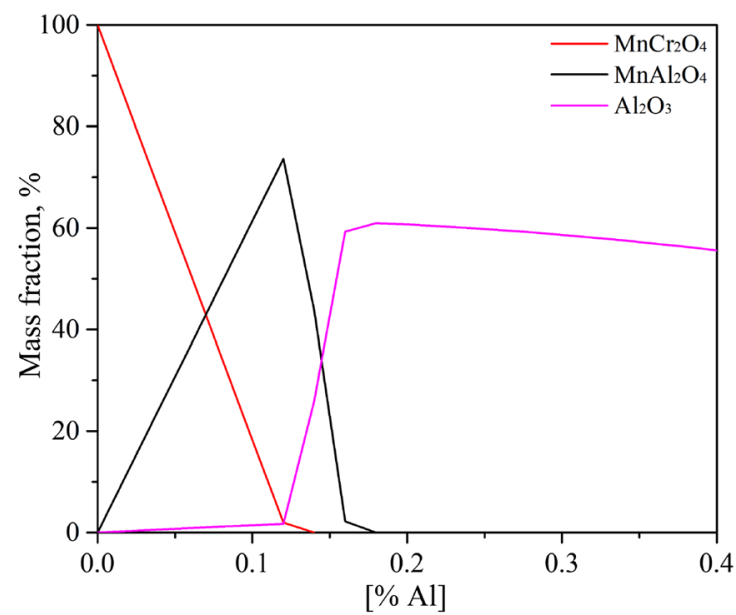

(a)

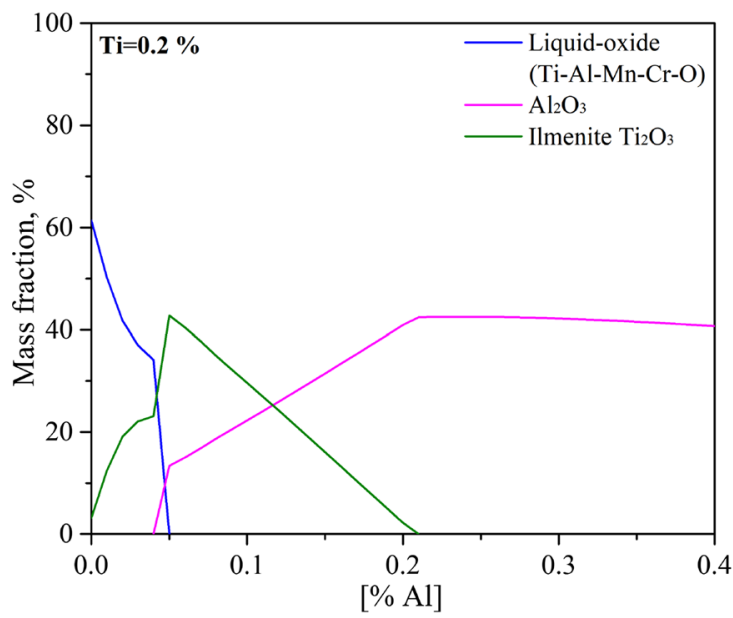

(c)

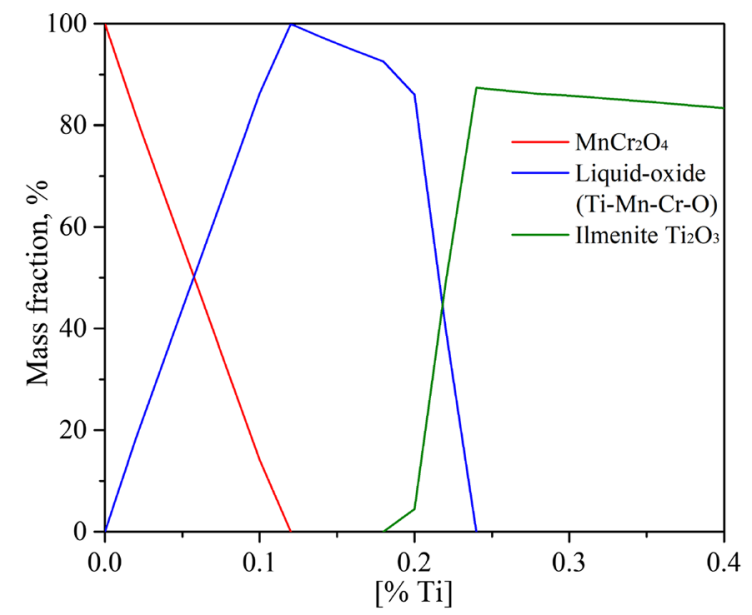

(b)

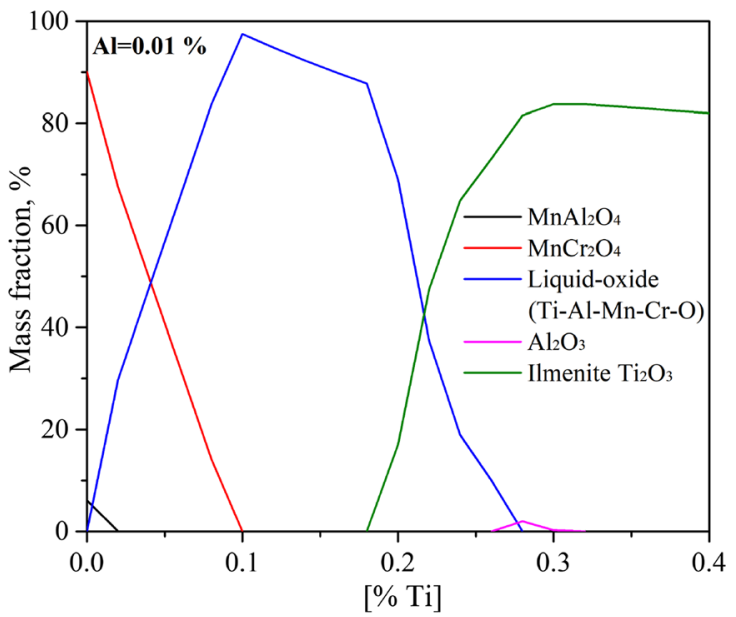

(d)

Fig. 12-Dependence of the stability of $\mathrm{MnCr}_{2} \mathrm{O}_{4}$ inclusions on the $\mathrm{Ti}$ and $\mathrm{Al}$ content at $1873 \mathrm{~K}\left(1600^{\circ} \mathrm{C}\right)(a)$ steel with only $\mathrm{Al}$, $(b)$ steel with only $\mathrm{Ti},(c)$ steel with $\mathrm{Al}$ and 0.2 mass pet $\mathrm{Ti}$, and $(d)$ steel with Ti and 0.01 mass pet $\mathrm{Al}$.

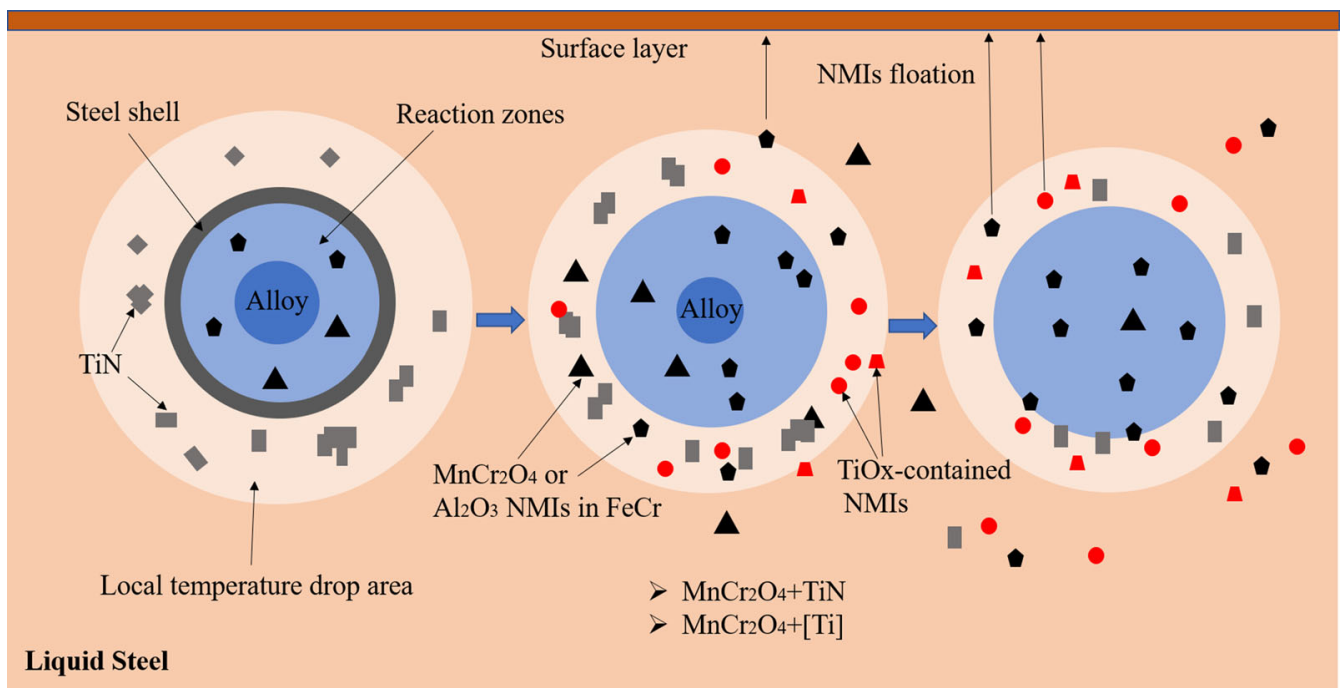

Fig. 13-Schematic illustration of the inclusion formations and transformations during the melting process of $\mathrm{FeCr}$ in steel. 
the $\mathrm{FeCr}$ alloy to form $\mathrm{TiO}_{x}$-containing inclusions. The dissolved $\mathrm{Ti}$ and $\mathrm{Al}$ in the melt can also reduce $\mathrm{MnCr}_{2} \mathrm{O}_{4}$ inclusions. However, the specific reaction mechanisms were found to depend on the ratio of $\mathrm{Ti} /$ $\mathrm{Al}$ in steel.

\section{ACKNOWLEDGMENTS}

Yong Wang acknowledges the financial support from the China Scholarship Council (CSC) and Jernkontoret. This research was partly supported by the Korea Evaluation Institute of Industrial Technology (KEIT, with Grant No. 20009956), funded by the Ministry of Trade, Industry \& Energy (MOTIE), Korea. Also, this research was partly supported by Korea Institute for Advancement of Technology (KIAT, with Grant No. P0002019), funded by the MOTIE, Korea. Yong Wang and Wangzhong $\mathrm{Mu}$ would like to acknowledge the Swedish Foundation for International Cooperation in Research and Higher Education (STINT with Project No. IB2020-8781).

\section{CONFLICT OF INTEREST}

On behalf of all authors, the corresponding author states that there is no conflict of interest.

\section{FUNDING}

Open access funding provided by Royal Institute of Technology.

\section{OPEN ACCESS}

This article is licensed under a Creative Commons Attribution 4.0 International License, which permits use, sharing, adaptation, distribution and reproduction in any medium or format, as long as you give appropriate credit to the original author(s) and the source, provide a link to the Creative Commons licence, and indicate if changes were made. The images or other third party material in this article are included in the article's Creative Commons licence, unless indicated otherwise in a credit line to the material. If material is not included in the article's Creative Commons licence and your intended use is not permitted by statutory regulation or exceeds the permitted use, you will need to obtain permission directly from the copyright holder. To view a copy of this licence, visit http://creat ivecommons.org/licenses/by/4.0/.

\section{REFERENCES}

1. S. Mehtonen, L. Karjalainen, and D. Porter: Mater. Sci. Eng. A, 2014, vol. 607, pp. 44-52.
2. L. Ma, S. Hu, J. Shen, and J. Han: Mater. Lett., 2016, vol. 184, pp. 204-207.

3. J. Cavazos, I. Gomez, and M. Guerrero-Mata: Mater. Sci. Technol., 2011, vol. 27, pp. 530-36.

4. M.H. Lee, R. Kim, and J.H. Park: Sci. Rep., 2019, vol. 9, pp. 1-11.

5. M.H. Lee and J.H. Park: Metall. Mater. Trans. B, 2018, vol. 49B, pp. 877-93.

6. J.H. Park: Calphad, 2011, vol. 35, pp. 455-62.

7. W. Yan, Y. Shan, and K. Yang: Metall. Mater. Trans. A, 2006, vol. 37A, pp. $2147-58$.

8. R. Maddalena, R. Rastogi, S. Bassem, and A. Cramb: Iron steelmak., 2000, vol. 27, pp. 71-79.

9. W. Mu, H. Shibata, P. Hedström, P.G. Jönsson, and K. Nakajima: Metall. Mater. Trans. B, 2016, vol. 47B, pp. 2133-47.

10. H. Todoroki and N. Shiga, In International Congress of Steelmaking, 2008, Cancun, Mexico, pp 121-24.

11. O. Wijk and V. Brabie: ISIJ Int., 1996, vol. 36, pp. S132-S135.

12. W. Li, Y. Ren, and L. Zhang: Ironmak. Steelmak., 2020, vol. 47, pp. $40-46$.

13. M. Li, S. Li, Y. Ren, W. Yang, and L. Zhang: Ironmak. Steelmak., 2020, vol. 47, pp. 1-6.

14. J.H. Park and Y.B. Kang: Metall. Mater. Trans. B, 2006, vol. 37B, pp. 791-97.

15. J.F. Xu, K.P. Wang, Y. Wang, Z.D. Qu, and X.K. Tu: J. Iron Steel Res. Int., 2020, vol. 27, pp. 1011-16.

16. K. Mizuno, H. Todoroki, M. Noda, and T. Tohge: Ironmak. Steelmak., 2001, vol. 28, pp. 93-101.

17. S.P. Piva and P.C. Pistorius: Metall. Mater. Trans. B, 2021, vol. 52B, pp. 6-16.

18. T. Sjökvist, M. Göransson, P. Jönsson, and P. Cowx: Ironmak. Steelmak., 2003, vol. 30, pp. 73-80.

19. M. Pande, M. Guo, X. Guo, D. Geysen, S. Devisscher, B. Blanpain, and P. Wollants: Ironmak. Steelmak., 2010, vol. 37, pp. 502-11.

20. M. Pande, M. Guo, and B. Blanpain: ISIJ Int., 2013, vol. 53, pp. 629-38.

21. M. Pande, M. Guo, S. Devisscher, and B. Blanpain: Ironmak. Steelmak., 2012, vol. 39, pp. 519-29.

22. P. Dorrer, S.K. Michelic, C. Bernhard, A. Penz, and R. Rössler: Steel Res. Int., 2019, vol. 90, p. 1800635.

23. T. Sjokvist: PhD thesis, KTH Royal Institute of Technology, 2001.

24. C.J. Guan and W. You: J. S. Afr. Inst. Min. Metall., 2020, vol. 120 , pp. $671-80$.

25. Y. Bi, A. Karasev, and P.G. Jönsson: Ironmak. Steelmak., 2014, vol. 41 , pp. $756-62$.

26. Y. Wang, A. Karasev, and P.G. Jönsson: Steel Res. Int., 2020, vol. 91 , p. 1900669.

27. M.W. Zhou and H. Yu: Int. J. Miner. Metall. Mater., 2012, vol. 19, pp. 805-11

28. F. Meng, J. Wang, E.-H. Han, and W. Ke: Corros. Sci., 2010, vol. 52, pp. 927-32.

29. M.B. Leban and R. Tisu: Eng. Fail. Anal., 2013, vol. 33, pp. 430-38.

30. J.H. Park, S.B. Lee, and H.R. Gaye: Metall. Mater. Trans. B, 2008, vol. 39B, pp. 853-61.

31. Y. Li, W. Yang, and L. Zhang: Metals, 2020, vol. 10, p. 444.

32. D. Zheng, J. Li, C. Shi, J. Zhang, and R. Geng: ISIJ Int., 2020, vol. 60 , pp. $1577-85$.

33. J.S. Park, C. Lee, and J.H. Park: Metall. Mater. Trans. B, 2012, vol. 43B, pp. 1550-64.

34. J.S. Park, D.H. Kim, and J.H. Park: J. Alloys Compd., 2017, vol. 695 , pp. 476-81.

35. X. Yin, Y.H. Sun, Y.D. Yang, X.F. Bai, M. Barati, and A. Mclean: Metall. Mater. Trans. B, 2016, vol. 47B, pp. 3274-84.

36. M. Hillert: J. Alloys Compd., 2001, vol. 320, pp. 161-76.

37. J.H. Park: Mater. Sci. Eng. A, 2008, vol. 472, pp. 43-51.

38. J.J. Pak, J.O. Jo, S.I. Kim, W.Y. Kim, T.I. Chung, S.M. Seo, J.H. Park, and D.S. Kim: ISIJ Int., 2007, vol. 47, pp. 16-24.

39. Y. Ren, L. Zhang, W. Yang, and H. Duan: Metall. Mater. Trans. B, 2014, vol. 45B, pp. 2057-71.

40. W.Y. Cha, T. Miki, Y. Sasaki, and M. Hino: ISIJ Int., 2006, vol. 46, pp. 987-95.

41. W.Y. Cha, T. Nagasaka, T. Miki, Y. Sasaki, and M. Hino: ISIJ Int., 2006, vol. 46, pp. 996-1005.

42. M.K. Paek, J.M. Jang, M. Jiang, and J.J. Pak: ISIJ Int., 2013, vol. 53, pp. $973-78$ 
43. J.J. Pak, Y.S. Jeong, I.K. Hong, W.Y. Cha, D.S. Kim, and Y.Y. Lee: ISIJ Int., 2005, vol. 45, pp. 1106-11.

44. J.J. Pak, J.T. Yoo, Y.S. Jeong, S.J. Tae, S.M. Seo, D.S. Kim, and Y.D. Lee: ISIJ Int., 2005, vol. 45, pp. 23-29.

45. H. Itoh, M. Hino, and S. Ban-Ya: Tetsu-to-Hagané, 1997, vol. 83, pp. $773-78$.

46. G. Sigworth and J.F. Elliott: Met. Sci., 1974, vol. 8, pp. 298-10.

47. Y. Gao and K. Sorimachi: ISIJ Int., 1993, vol. 33, pp. 291-97.

48. W.Y. Kim, J.O. Jo, T.I. Chung, D.S. Kim, and J.J. Pak: ISIJ Int., 2007, vol. 47, pp. 1082-89.

49. J.O. Jo, W.Y. Kim, C.O. Lee, and J.J. Pak: ISIJ Int., 2010, vol. 50, pp. $1373-79$.

50. M.K. Paek, K.H. Kim, D. Lindberg, and J.J. Pak: Steel Res. Int., 2020, vol. 15 , p. 2000508.

51. P.C. Lu, H.B. Li, H. Feng, Z.H. Jiang, H.C. Zhu, Z.Z. Liu, and T. He: Metall. Mater. Trans. B, 2021, vol. 52B, pp. 2210-23.
52. C. Pan, X.J. Hu, P. Lin, and K.C. Chou: Metall. Mater. Trans. B, 2020, vol. 51B, pp. 3039-50.

53. L. Pandelaers, F. Verhaeghe, B. Blanpain, P. Wollants, and P. Gardin: Metall. Mater. Trans. B, 2009, vol. 40B, pp. 676-84.

54. H. Duan, L. Zhang, and B.G. Thomas: Steel Res. Int., 2019, vol. 90, p. 1800288.

55. C. Zhang, Y. Bao, D. Tang, C. Ji, L. Wang, Y. Cui, and H. Li: ISIJ Int., 2018, vol. 58, pp. 2262-70.

56. Y. Wang, A. Karasev, J.H. Park, and P.G. Jönsson: ISIJ Int., 2021, vol. 61, pp. 209-18.

57. Y. Wang, A. Karasev, W.Z. Mu, JH. Park, and P.G. Jönsson: Metall. Mater. Trans. B, 2021, vol. 52B, pp. 2459-73.

Publisher's Note Springer Nature remains neutral with regard to jurisdictional claims in published maps and institutional affiliations. 